DOI: 10.25178/nit.2018.4.3

\section{ТУВИНСКИЙ \\ (НЕО)ШАМАНИЗМ \\ КАК КУЛЬТОВАЯ \\ И ЦЕЛИТЕЛЬСКАЯ \\ ПРАКТИКА В \\ СОВРЕМЕННОМ МИРЕ"}

TUVAN

(NEO) SHAMANISM

AS A RELIGIOUS

AND HEALING PRACTICE IN CONTEMPORARY WORLD

\section{Валентина И. Харитонова}

Институт этнологии и антропологии им. Н. Н. Миклухо-Маклая

Российской академии наук, Российская Федерация

\author{
Valentina I. Kharitonova \\ Institute of Ethnology and Anthropology, \\ Russian Academy of Sciences, \\ Russian Federation
}

В статье на основе полевых и лабораторных материалов автора 2000-2018 22., многочисленных публикаций в СМИ, зарисовок ТВ и видео-записей этого периода рассматривается современная культурно-религиозная ситуация в Республике Тыва и ее отголоски в разных странах мира. Анализируются аспекты культовой и целительской деятельности лиц, соотносящих свою практику с (нео) шаманизмом. Автор исследует трансформации и значимую модернизацию тувинского шаманизма в постсоветский период. Приводятся примеры особенностей практики отдельных тувинских (нео)шаманов и их учеников из иных российских регионов.

В ситуации культурной глобализации наблюдается поток российских и западных туристов в Туву,

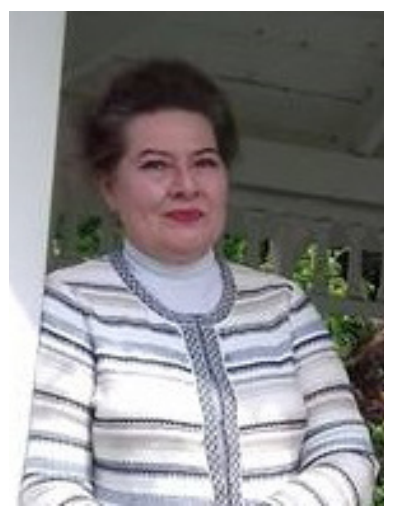

The article examines present-day cultural and religious situation of the Tuvans in the republic of Tuva, as well as its implications in different countries. The study is based on the field and laboratory materials collected between 2000 and 2018, on multiple publications in mass-media, TV footage and video recordings from that period. Some aspects of religious work and healing by those describing their practice as (neo) shamanic have been analyzed here, and some examples of practices of individual Tuvan (neo) shamans and their disciples from different Russian regions are described. The author looks at the transformations and significant modernization shamanism has experienced in the post-Soviet period.

\footnotetext{
* Исследование выполнено в рамках проекта РФФИ (РГНФ) «Проблемы интеграции медицинских систем, практик и методов в контексте медицинской антропологии» (грант № 17-01-00434-a).

The study was made in the framework of project "Problems of integration of medical systems, practices and methods in the field of medical anthropology”, supported by a grant from RFBR / RFH No. 17-01-00434-a

Харитонова Валентина Ивановна - доктор исторических наук, главный научный сотрудник, заведующая Центром медицинской антропологии Института этнологии и антропологии им. Н. Н. Миклухо-Маклая Российской академии наук; президент Ассоциации медицинских антропологов (Россия); главный редактор журнала «Медицинская антропология и биоэтика». Адрес: 119991, Россия, г. Москва, Ленинский проспект, д. 32А, каб. 1804. Тел.: +7 (495) 954-80-09. Эл. адрес: medanthro@mail.ru

Kharitonova Valentina Ivanovna, Doctor of History, Leading Researcher, Head of Center of Medical Anthropology, Institute of Ethnology and Anthropology, Russian Academy of Sciences; President, Association of Medical Anthropology (Russia); Editor-in-chief of "Medical Anthropology and Bioethics" journal. Postal address: Room 1804, 32A Leninskiy prosp., Institute of Ethnology and Anthropology, Moscow, 119991 Russian Federation. Tel.: +7 (495) 954-80-09. E-mail: medanthro@mail.ru
} 
которые стремятся к приобщению/посвящению в шаманы. Сюда едут и исследователи шаманизма. Тувинские (нео)шаманы, в свою очередь, выезжают в крупные города России и разные страны мира. Там они знакомят слушателей с тувинской сакральной культурой, жреческими ритуалами, целительскими и лечебными практиками. Обживая чужое пространство, (нео)шаманы даже сооружают там свои священные места - оваа, оставляя их для дальнейшего использования местным жителям.

Трансформации современного «шаманизма» Тувы диктуются изменениями законодательства в отношении религий (шаманизм объявлен одной из традиционных религий Республики Тыва), социиально-экономическими сложностями, проблемами в здравоохранении. Важными факторами в этом процессе выступают: национально-культурное возрождение, акцентирующее внимание на восстановлении обрядовой культуры и шаманства; интерес к определенным направлениям психологии, трансцендентному, эзотерике и возможности получения ранее запрещенных знаний и опыта. Меняется практика шаманизма, меняется контингент практикующих.

Ключевые слова: шаманизм; (нео)шаманизм; городской шаманизм; духовные практики; шаманское целительство; эзотерика; религиозная система; культовая практика; народная медицина; профилактика и оздоровление; ИСС; измененные состояния сознания; Тува; тувинцы
Cultural globalisation has led to a flow of Russian and foreign tourists in Tuva, seeking shamanic experience or wishing to become a shaman. The researchers of shamanism also go there. Tuvan (neo) shamans, in their turn, visit cities of Russia and foreign countries, where they present to their listeners the Tuvan sacred culture, devotional rituals, healing and medical practices. In making these foreign spaces their own, they even construct sanctuaries, known as ovaa, and leave them for further use by the local residents.

The transformation of modern Tuvan "shamanism" is mandated by changes in legislation on religions (shamanism is the official religion of the republic of Tuva), by social and economic challenges, as well as problems with health care. Other important factors include the national and cultural revival with its focus on rebirth of ritual culture and shamanism; an enduring interest in certain aspects of psychology, the transcendent, esotericism and studying previously forbidden knowledge and experience. The practice of shamanism is changing, and so does the contingent of its practitioners.

Keywords: shamanism; (neo) shamanism; urban shamanism; spiritual practice; shaman healing; esotericism; religious system; religious practice; folk medicine; prevention and recovery; ASC; altered states of consciousness; Tuva; Tuvans

\section{Введение}

Что такое шаманизм? Вопрос до сих пор остается открытым, хотя, казалось бы, об этом многомерном и многоплановом явлении написано множество научных трудов (Shamanism. An Encyclopedia ..., 2004), в том числе и теми людьми, которые считают себя (или считаются другими) шаманами. Не менее «загадочным» представляется новшество, обозначаемое модифицированным термином (нео)шаманизм¹ (там же: 52-53; Харитонова, 2006a, 2013ab). Одна из важнейших проблем характеристики этого феномена связана с тем, что русским по огласовки словом «шаман» называют разных специалистов, которые в национальных языках обычно именовались совсем по-иному (кстати, в

\footnotetext{
${ }^{1}$ Написание слова (нео)шаман (с дополнительными скобками, выделяющими часть слова) подчеркивает невозможность четко определить точный статус исследуемого объекта в современных условиях (практикующие «шаманизм» могут обладать некоторым набором традиционных знаний, но в большинстве случаев они ориентируются на современные неошаманские представления и ритуальную деятельность).
} 
некоторых культурах насчитывается более десятка различных специалистов, которые - при полном несовпадении своих наименований, далеком от слова «шаман», - учитывая их связь с сакральными практиками, объединяются русскоязычными и англоязычными исследователями в одну группу).

В наборе наименований сакральных или близких к ним специальностей (что исследователи могут включать в единый комплекс - «шаман») в любой культуре трудно не заметить важнейшее разграничение двух групп лиц: тех, кто связан с культово-религиозной деятельностью, и тех, кто нацелен преимущественно на магико-медицинские практики, занимается профилактикой и оздоровлением / лечением. Два аспекта деятельности условного «шамана» (термин чаще всего считают тунгусоязычным по происхождению) могут сближаться друг с другом в зависимости от особенностей жизни и культуры определенных народов. Но за разграничением деятельности специалистов двух групп стоит не только ориентация на жреческую или медицинскую практику; что гораздо важнее - их разделяют специфические способности, которые необходимы для осуществления той или другой деятельности. Это - психофизиологические особенности функционирования организма и нейрофизиологическая специфика работы мозга (см. об этом подробно: Харитонова, 2001ab, 2004, 2005; Харитонова, Топоев, 2005; Харитонова, Свидерская, Мещерякова, 2006, Kharitonova, Ukraintseva, 2012 и др.; см. также, например: Кальвайт, 1998, Winkelman, 2004; Krippner, 2004).

Интердисциплинарные исследования показывают эти различия. Жрецу, который должен осуществлять связь сообщества с божествами, вымаливая необходимое для благополучной и счастливой жизни, важно точно воспроизводить обращения к высшим силам, чтобы не сделать чего-то неправильно. В таком случае, ему надо иметь хорошую память и обладать навыками воспроизведения текстов (скажем, тувинских алгышей1). Даже с учетом того, что известные тексты воссоздаются и воспроизводятся разными людьми по-разному, ни один, ни другой процесс не требует погружений в глубокие стадии измененного состояния сознания (ИСС). А вот для профессиональной практики шамана-целителя или ясновидца-предсказателя нужно именно это довольно глубокое погружение, поскольку у них иные задачи и даже тексты они больше и чаще создают, в лучшем случае воссоздают, а не воспроизводят (см. подробно об обращении исполнителя с текстом: Харитонова, 1999).

Сторонними наблюдателями, в т. ч. некоторыми шаманистами, регулярно присутствующими на разных ритуалах (камланиях), такие специалисты не всегда четко дифференцируются, да и сами они порой выполняют несколько разных функций с различным успехом. Видимо, в том числе поэтому в ситуации внесения шаманизма в официальный список традиционных религий в республиканских документах, например в Туве (наряду с буддизмом и

\footnotetext{
${ }^{1}$ Алгыши - вид обрядовой поэзии: заклинания, напутствия, благословления, исполняемые шаманами.
} 
православием, см.: Закон Республики Тыва ..., Электр. ресурс), произошла некоторая переориентация практиковавших в то время (нео)шаманов, которые ориентировались на целительскую деятельность и решение семейно-бытовых проблем. Они, соглашаясь на официальный статус религиозных деятелей, фактически, в обмен на освобождение от налогов, должны были осуществлять жреческую практику в первую очередь, сообразно целям и задачам, определенным в уставах местных религиозных организаций шаманов (МРОШ), которые официально регистрировались в республиках.

Дала ли что-то эта переориентация самим практикующим, расширяя сферу их деятельности? Возможно. Но пока - это вопрос, требующий дополнительных исследований. Он будет отчасти затронут в данной статье, основной целью которой является демонстрация трансформаций, произошедших с начала перестройки и происходящих до настоящего времени в сфере того объемного явления, какое сейчас именуется словом «шаманизм» или «неошаманизм», в Туве, а также других регионах России и за рубежом; трансформаций, меняющих сам феномен шаманизма и приобщенных к нему людей, даже их психофизиологию, а порой и психику. Рассматривая круг избираемых для пристального анализа (нео)шаманов и их деятельность как основной предмет исследования, ориентированного на качественные методы, я буду анализировать современную культурно-религиозную ситуацию, в первую очередь проявления культовой и целительской практики, связываемые с представлением о (нео)шаманах, включая вместе с ними в объект исследования иные сферы деятельности интересующих меня специалистов (например, административную, а также их социальные функции, творчество).

При таком подходе основной источниковой базой станут полевые наблюдения и материалы автора, собиравшиеся с начала 2000-х годов в Республике Тыва и других российских регионах, а также лабораторные данные, получаемые в ходе научно-практических семинаров, проводимых по настоящее время; публикации в СМИ, интернет-источники, видеозаписи. Поскольку многие авторские материалы были обобщены и проанализированы в более ранних публикациях, то для краткости изложения я буду давать отсылки к этим работам.

\section{(Нео)цаман: это «новый иаман» или продолжающий традиции предков жрец - целитель - ясновидящий?}

Во второй половине XX века представители разных народов (даже тех, у которых шаманизма как такового в культуре никогда не было) заинтересовались этим сложным феноменом, восприняв различные его аспекты. На американском континенте, а потом в Европе стали распространяться разные варианты того, что соотносили с практиками шаманизма (как жречества, так и целительства, но в новом варианте это были уже преимущественно поиски 
духовных истин с задачами психической саморегуляции: см., напр.: Ингерман, 2001, ср.: Харитонова, 2016bc; см. также: Nauwald, 2015). Термин «шаманизм» на Западе соотносится уже на рубеже XX-XXI вв. с идеей гармонии с природой, о чем писала, например, антрополог Г. Линдквист (Lindquist, 1997): скандинавские неошаманы являются поборниками экологического движения. Но интерес к феномену шаманизма начался с разрешения древних практик индейцев властями Канады и СШАв в 1950-1960-е гг. в период национального ренессанса (Jilek,1982) и с деятельности антрополога М. Харнера (Harner, 1980), посвятившегося у индейцев в шаманы и создавшего позже на основе своих знаний и практики облегченный вариант погружений в ИСС, сохраняя в нем основу, что было названо Corn Shamanism («ядро шаманизма») (Townsend, 2004: 49-52). Профессор Харнер со своими сподвижниками организовал мировую сеть обучения этой практике (Фонд исследований шаманизма: https://www.shamanism.org). Развитию этого интереса способствовали также захватывающие романы ещё одного антрополога Карлоса Кастанеды. В конце XX в. по всему миру стали распространяться облегченные варианты погружения в ИСС под звуки бубнов, варганов, трещоток.

Надо вспомнить ещё о том, что одновременно с антропологами и психологи устремились в пределы трансперсонального (тоже в различных вариантах, но более всего у нас стали известны последователи С. и К. Гроф (см., напр.: Гроф, 1993, 2018), благодаря активной практической и публикационной деятельности Владимира Майкова (https://www.vmaykov.ru/). Не забудем про развивающийся в то же время интерес к традиционным медицинам Востока и буддизму, с которым они ассоциируются, равно как и устремленность к постижению тайн парапсихологии, да и просто магии... Всё это привело к настойчивому желанию познавать эзотерику и оккультизм. Смешалось все: наука, около-наука, ненаука; здравый смысл и шизофрения; остатки религиозных традиций и неорелигиозные практики; появились пророки и ясновидцы, маги и колдуны, «белые ламы» и «черные ведьмы»... (см. подробно: Харитонова, 2000).

Среди этой мешанины на фоне национально-культурного возрождения с интересом к родным языкам и фольклору начали активизироваться культурные лидеры в Южной Сибири: появился интерес к возрождению своих традиционных праздников, а вместе с ними - своего шаманизма (см. например: «Избранники духов» ... , 1999; Харитонова, 2001bc; Женщина ... , 2005; Пименова, 2007 и др.). Надо сказать, что в Якутии, Бурятии и особенно в Туве для этого были все основания: в республиках ещё практиковали последние традиционно посвящавшиеся шаманы. В 2000 г., например, в разговоре со мной д. ист. н., занимавшийся изучением и сохранением тувинского фольклора и этнографии, в первую очередь шаманских практик, М. Б. Кенин-Лопсан по своей картотеке назвал более десятка ещё живших и практиковавших на окраинах Тувы старых шаманов: Харитонова, Кенин-Лопсан, $2000^{1}$ ), а в среде шаманствующих, т. е. приобщенных к

${ }^{1}$ На сайте «Профессиональной лиги Психологии и психотерапии» https://n543.ru/mongush-boraxovich-keninlopsan.html с нарушением авторских прав перепечатан текст моего интервью с М. Б. Кенин-Лопсаном. 
шаманскому искусству, было много знатоков традиции (см., например: Kharitonova, 2005). Они в случае необходимости могли проконсультировать по самым разным вопросам тех, кто выразил готовность взять на себя нелегкую ношу быть шаманом, которая, правда, кое-кому казалась больше развлечением, чем «тяжким бременем» (Штернберг, 1927); впрочем, в итоге для многих это и стало развлечением или способом заработать на жизнь.

Традиция начала восстанавливаться, однако в несколько необычных формах (Харитонова 2006а, 2008): появились шаманские центры (сначала просто шаманские объединения, а потом религиозные организации, зарегистрированные согласно Федеральному закону от 26.09.1997 № 125 -ФЗ «О свободе совести и о религиозных объединениях» (Федеральный закон ... , Электр. ресурс)). Любопытным фактом, на который любят обращать внимание исследователи, было и своеобразное структурирование таких объединений. За образец они взяли известные во всем мире партийно-профсоюзные варианты «лестницы»: от первичной ячейки (МРОШ) к централизованной организации - с привычными всем нам собраниями, выборами, постановлениями и даже выговорами и наказанием, например, за пристрастие к алкоголю (известно, что из МРОШ могли «отчислить» за такое поведение), а также выдачей членских билетов - шаманских удостоверений: от простых членов МРОШ до подтверждения звания Улуг кам Великий шаман (например, такое удостоверение от М. Б. Кенин-Лопсана получил К. Т. Допчун-оол, глава МРОШ «Адык Ээрен»).

Велик соблазн рассматривать это только как воздействие советского менталитета, наличие партийно-профсоюзных и комсомольско-пионерских образцов в нашем сознании (Харитонова, 2006a, 2016b; Пименова, 2007, Pimenova, 2013 и др.). Однако, речь должна идти о естественном стремлении к объединению, централизации, а также устремленности лидеров, возглавлявших конкретные МРОШ, стать ещё более значимыми фигурами - объединить всех шаманов Сибири или даже России, выбрать «духовного лидера» с представительством на уровне Москвы, Кремля и пр., и пр. Это вело к тому, что ряд лиц попытались реализовать свои личные амбиции, в т. ч. в Туве.

Думаю, не стоит говорить о более раннем странном инциденте 2008 г. на уровне Интернета с «выборами Верховного шамана» России, организованного Олардом Диксоном (псевдоним Олега Паршина) и его супругой Шончалай Ховенмей (псевдоним Виктории Шалгыновой). В этом действе была попытка ссылаться на поддержку М. Б. Кенин-Лопсана. Но тогда именно тувинские шаманы в лице А. Ш. Оюн, возглавлявшей «Тос Дээр», отвергли идею. Недавно же некие выборы состоялись (Скрыльников, 2018: Электр. ресурс), и К. Т. Допчун-оол, глава МРОШ «Адык Ээрен», был объявлен верховным шаманом. Понятно, что при всей имитации международных выборов, это избрание не имеет повсеместной поддержки со стороны шаманов и официально признанного статуса, поскольку (нео)шаманизм, даже в его проявлениях последних лет - все 
большем обращении к жреческим функциям и отходе от сложной целительской работы, слишком разобщен, а большинство имеющих к нему отношение вряд ли стремятся к такой консолидации. Тем не менее прецедент имеет место.

Интересно, что помимо создания МРОШ уже в начале 2000-х годов возникали и иные формы, необычные для классического шаманизма: в Туве, например, шаманом С.И.Канчыыр-оолом была создана Школа шаманизма, подготовившая нескольких учениц. Ещё в 1990-е годы новые шаманы стали активно проводить семинары по шаманизму - для приезжавших в Туву и на выезде - чаще всего в Москве; в то же время они устремились за пределы России, в дальние страны. Тогда же организаторы шаманского движения, среди которых были дипломированные ученые в том числе, взяли курс на консолидацию с наукой, проводя конференции совместно с учеными из различных российских организаций и приезжающими из зарубежных стран (шамановеды обычно рассматривали такие мероприятия как своего рода исследовательское поле).

С учетом всего этого и надо отвечать на вопросы: что получила через пару десятилетий культура - (нео)шаманов или традиционных шаманов, приспособившихся к новым условиям жизни? Что дали эти трансформации самим практикующим? А, может быть, это и вообще уже иные специалисты - не шаманы (см. подробно: Харитонова, 2006b)? На такие размышления наводят приведенные выше факты все большего отхода от естественных для традиционного шаманизма практик (ср., например: Дьяконова, 1972; Shamanism in Siberia, 1978; Вайнштейн, 1990, 1991), да и «братство народов» в шаманских организациях, где с момента их создания могли работать приезжающие специалисты от самых разных традиций (это имело место во всех МРОШ Кызыла); некоторые из гостей уверенно объясняли, например, что колдовские практики и шаманские не противоречат друг другу.

Надо сказать, что стремление к «глобализации шаманизма» и объединению, несмотря на культурные различия (естественно, с внутренним структурированием, той же «лестницей»), заданное М. Харнером и его Фондом изучения шаманизма, реализуется и в иных вариантах - в большей степени творческих, но с некоторыми религиозными акцентами (устремлением к объединению всех религий, что свойственно в целом практикам Нью Эдж). Обратим внимание, например, на проводимый ежегодно в Туве по инициативе Н. М. Ооржака фестиваль «Зов 13-ти шаманов» (Шаманы мира в Центре Азии) - мероприятие, выходящее за пределы представлений о шаманизме (http://13shamans.ru/ru/). Оно собирает представителей современных практик из разных стран мира, ассоциирующих себя, в том числе, с шаманизмом. В этом году почетным гостем фестиваля был... лама Лопсан Чамзы - глава буддийской религиозной организации Камбы-Лама Республики Тыва.

Вот как рассуждает на тему глобализации шаманизма этнограф и фольклорист, объявивший себя в 1990-е годы Верховным шаманом Тувы, д. и. н. М. Б. Кенин- 


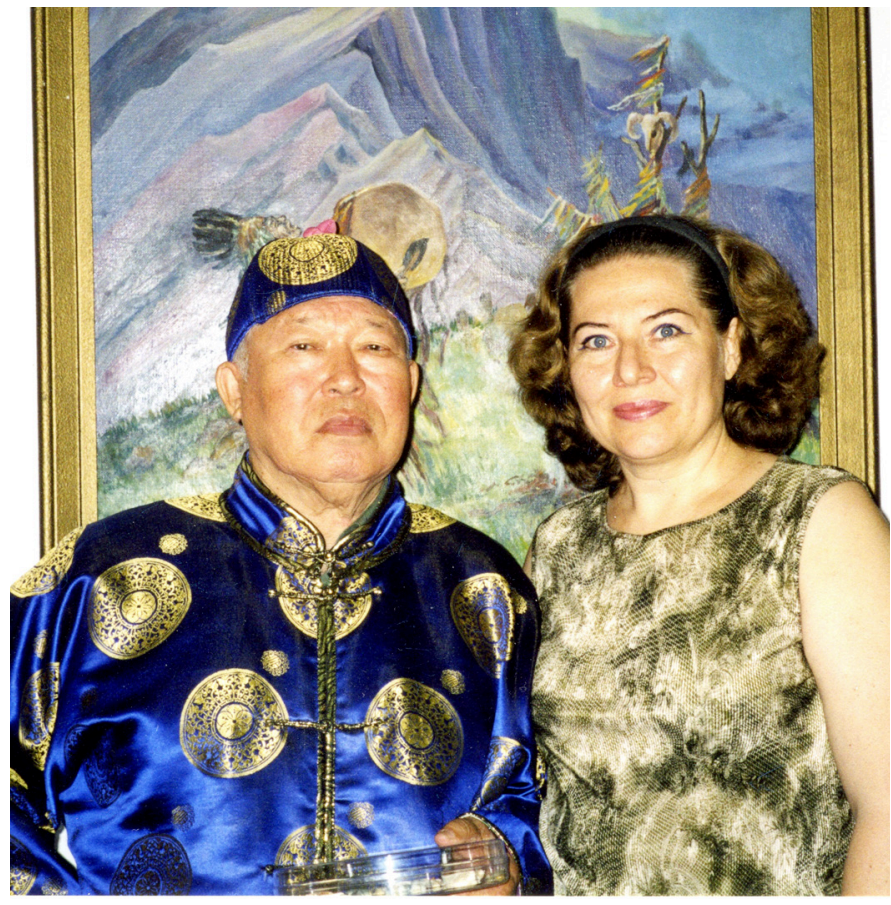

Фото 1. Монгуш Кенин-Лопсан и Валентина Харитонова, фото Т. А. Ондар, 20032.

Photo 1. Mongush Kenin-Lopsan and Valentina Kharitonova. Photo by T. A. Ondar, 2003.

Лопсан (см. его работы: КенинЛопсан, 1987, 2006, 2009): «В принципе, мы открыты для всех. У нас много учеников из Тувы и из остальной Сибири, из Москвы, Петербурга, есть немцы, англичане, американцы, французы. Всем, кто проходит курс обучения, мы выдаем свидетельства об окончании Научного центра по изучению тувинского шаманства, что еще не означает статуса шамана. Таковым человек должен почувствовать себя сам и научиться входить в состояние общения с духами. Мы можем только удостовериться, умеет или не умеет соискатель входить в это состояние» (Монгуш Кенин-Лопсан: ... , 2007: Электр. ресурс). От новых шаманов (особенно городских шаманов) можно услышать рассуждения на тему о том, что чем больше посвящений (следовательно, знаний) получил шаман, тем это лучше, так как он повышает свой статус и развивает шаманские способности.

Свои способности современные шаманы развивают, прибегая к изучению разных направлений психологии (с последующим использованием некоторых психологических приемов и навыков в своей практике). Наблюдается двустороннее движение: шаманы устремляются изучать психологию, а психологи стремятся стать шаманами или хотя бы приобщиться к загадочным техникам шаманизма. Интересно, что современные (нео)шаманы часто обращаются к этнографическим изданиям для использования при «возрождении традиций» сведений оттуда. У некоторых из них есть настойчивые попытки понять через научные исследования, в т. ч. с помощью естественных и медицинских наук, что за странности приключаются с ними в их «шаманских путешествиях». Если внимательно изучать великое множество нынешних практикующих разные «шаманизмы», то среди них найдутся люди, осваивавшие все перечисленное и даже значительно больше (см.: Харитонова, 2009, 2016а). Но это не задача данной статьи.

Здесь важно рассмотреть на конкретных примерах трансформации культовой деятельности тувинских и примкнувших к ним (нео)шаманов, ориентировавшихся на продолжение традиций и на сохранение шаманского/духовного целительства. 


\section{Drang nach Westen ${ }^{1}$}

Вот типичное сообщение о деятельности тувинских (нео)шаманов, как нельзя лучше характеризующее произошедшие на рубеже веков трансформации в практике шаманизма: «Один из самых востребованных на Западе шаманов Тувы - шаман общества “Дунгур” (Бубен) Дугар-Сюрюн Очур-оолович Ооржак вернулся в республику после серии семинаров в городах Австрии. Он знакомил европейцев с практиками шаманов центра Азии» (Оюн, 2012: Электр. ресурс).

Разумеется, Д. О. Ооржак - не единственный шаман, который практикует за пределами Тувы и России. Такие поездки - то в варианте культурных вояжей (например, презентация книги М. Б. Кенин-Лопсана в Гамбурге, в этнографическом музее, см.: В Германии издана ..., 2011: Электр. ресурс), то как просто коммерческие выезды с целью заработать на проведении семинаров или обрядов - предпринимают многие практики осовремененного шаманизма. Их позиция понятна. Сложнее понять принимающую сторону: в европейских странах, как и в США, Канаде их ждут не только с культурными программами, но и предлагают проведение семинаров, консультаций и даже... просят лечения (хотя, очевидно, что эти оздоровительно-лечебные услуги оказываются незаконно).

При всей, на первый взгляд, странности ситуации, я могу подтвердить это не только как исследователь, знающий о происходящем из различных печатных источников и от зарубежных коллег, но и как свидетель, лично наблюдавший, например, бережное сохранение и использование по назначению оваа - священного места, созданного под руководством Ай Чурек Шиижиковны Оюн на севере Италии. Ай Чурек впервые была приглашена в Валле-де-Аосту в 1998 г. А. Содэн, советником по связям с Россией, Украиной и Белоруссией регионального Министерства туризма ${ }^{2}$ А. Содэн сняла вместе с К. Аллионе фильм о тувинском шаманизме; они также написали книгу о самой Ай Чурек (Saudin, Allione, 1999). Оваа было создано руками не только приехавших по приглашению женщин, но и местных помощниц, в первую очередь самой А. Содэн. Потом здесь проводились ритуалы и осуществлялась, в том числе, целительская практика.

Поле ухода из жизни Ай Чурек в 2010 г. ее оваа по-прежнему сохраняется и используется по назначению местными жителями, а также приезжающими неошаманами и туристами (Харитонова, 2014: Электр. ресурс).

Надо сказать, что в начале 2000-х годов Ай Чурек много ездила по разным странам мира. Вот, например, сообщение от 2 декабря 2003 г.: «Ай-Чурек, председатель Централизованной Религиозной Организации тувинских шаманов “Тос-

\footnotetext{
${ }^{1}$ Стремление на Запад (нем.).

2 Это было приглашение на конгресс, организованный на базе университета Вероны профессором Gabriel Maria Sala. Второй раз А. Ш. Оюн приезжала в Валле д’Аосту в 1999 г. В июле следующего 2019 года в Валле д’Аоста будет отмечаться 20-летие постройки оваа.
} 
Дээр” (9 небес), более известная за рубежом (ритуалы и семинары в США, Италии, Швейцарии, Германии, запись в США совместного с группой “Кронос-Квартет” диска), впервые после нескольких кратких посещений Москвы решила сосредоточить свое внимание на столице. С 4 по 21 декабря она проведет здесь полный цикл ритуалов и семинаров» (Тувинская шаманка ..., 2003: Электр. ресурс); а вот от 2 апреля 2004 г.: «Завтра в США начнутся выступления и семинары тувинской шаманки Ай-Чурек и фольклорной группы “Чиргилчин”. Для них - это не первый приезд в Америку. Первый семинар, посвященной древнему верованию тувинцев, АйЧурек проведет в г. Ярмуте (штат Мэн), география ее выступлений охватит в дальнейшем города штата Калифорния» (Оюн, 2004: Электр. ре-

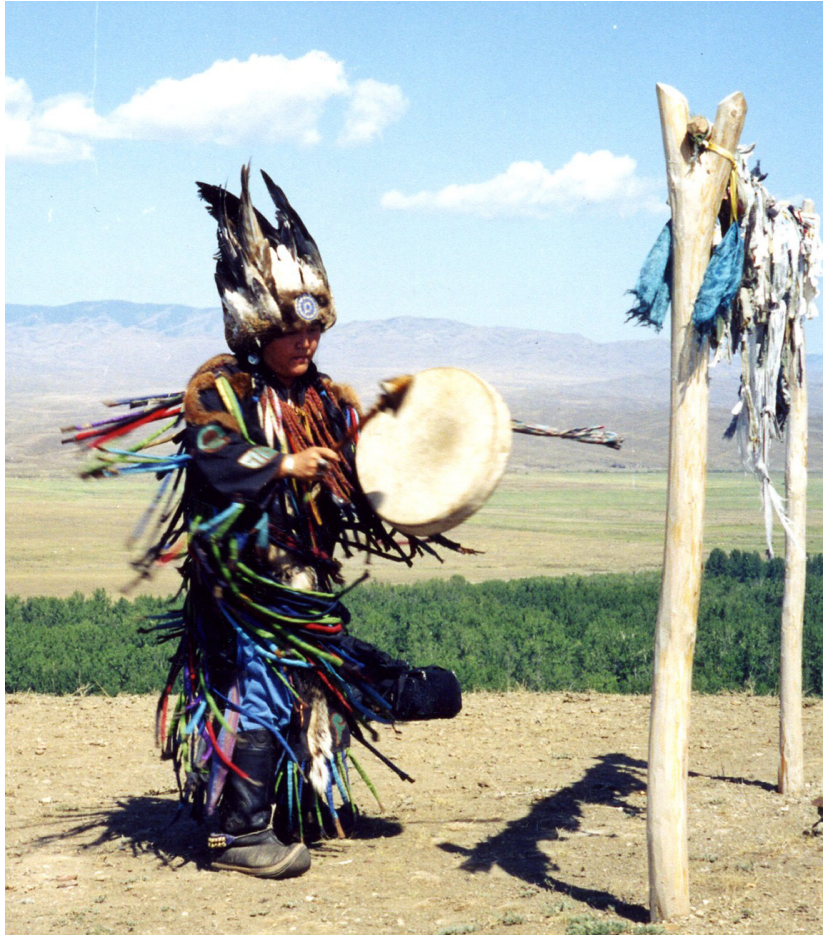

Фото 2. Ай Чурек Шиижиковна Оюн, руководитель МРОШ «Тос Дээр», фото В. И. Харитоновой, 20012. Photo 2. Ai Churek Shiizhikovna Oyun, head of Tos Daer local shamanic religious organization. Photo by V. I. Kharitonova, 2000. сурс). В плане собственно лечения и «очищения» наиболее интересно такое сообщение: «Как стало известно сегодня, на сентябрь запланирован приезд в США шаманки Ай-Чурек (Лунное сердце). Она широко известна как одна из наиболее сильных и уважаемых шаманок Тувы. Ай-Чурек проводит не только лечебные сеансы, но и церемонии очищения. В течение месяца тувинская шаманка будет работать в Сан-Франциско. Ожидается, что она будет вести и частный прием» (Слон, 2002: Электр. ресурс).

Выезжающие на Запад шаманы предлагают там свои услуги в том варианте, который требуют обстоятельства. Но вопрос о лечебной, оздоровительной функции остается, как правило, на первом плане: к ним обращаются за консультациями и в серьезных ситуациях (с наличием диагностированных заболеваний), и ради профилактики - в таком случае речь идет о духовной поддержке: очищении человека, восстановлении его связи с родом, предками, «открытии дороги».

На самом деле за проведением семинаров стоит именно оказание услуг по запросам. Обычно шаманы рассказывают о своей практике с примерами исцеления или изменений жизненных ситуаций в результате своего воздействия. Рассказ может сопровождаться сообщением о личном шаманском становлении - с описанием трудностей «шаманской болезни» и их преодоления. Наши специалисты являются одновременно своеобразными 56 


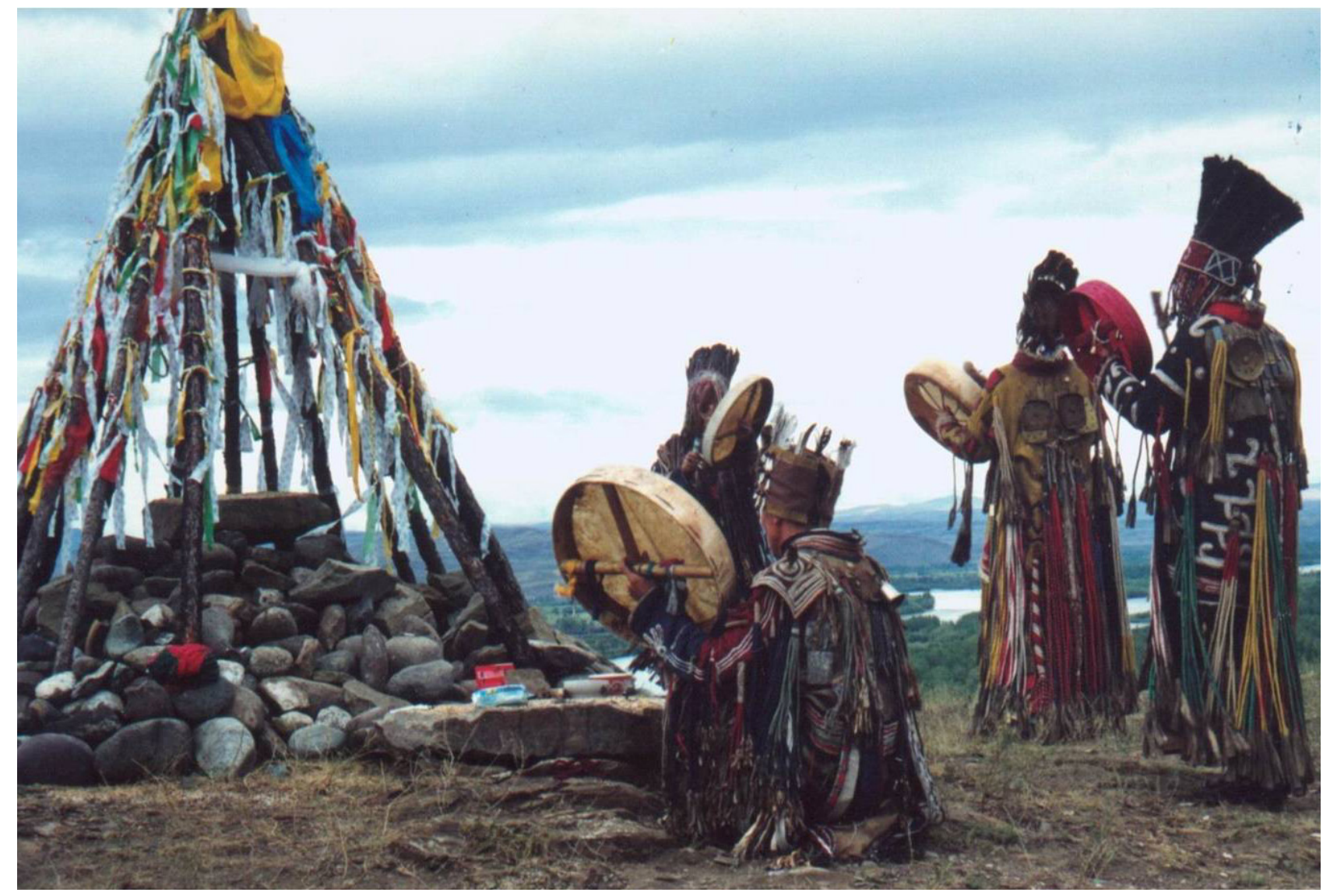

Фото 3. Камлание шаманов МРОШ «Тос Дээр» на новом священном месте - оваа, фото В. И. Харитоновой, 2000 г.

Photo 3. Shamanic ritual of Tos Daer at a new ovaa, a natural shrine. Photo by V. I. Kharitonova, 2000.

проводниками своей культуры: на семинарах они демонстрируют ритуальные действа, горловое пение хоомей, исполняют (если знают и умеют) шаманские песнопения (тувинские алгыши), рассказывают об особенностях культуры своих народов (понятно, что в этих рассказах может быть достаточно личных фантазий, поскольку в советский период получение таких знаний, особенно из сакральной сферы, было ограничено: см.: Харитонова, 2016а).

Культурная миссия шамана в современном мире сводится не только к информации и распространению сведений о наследии своего народа. В конце XX-го - XXI-м веках спрос на «тайное знание», особенно «шаманское», резко возрос (см.: Харитонова, 2006а и др.). Стремление обрести его и получить некое «посвящение» свойственно многим людям в разных странах и на разных континентах. В Туву, которая манит своей таинственностью многих искателей тайного знания, с начала 1990-х годов стали приезжать и российские жители, и иностранцы (благодаря тому, что страна открыла свои границы).

Интересно, что у тувинских шаманов уже в эти годы появились ученики разных национальностей. Мне приходилось не раз писать о конкретных личностях, вставших на путь изучения традиций тувинского шаманизма, которые, 
кстати, и спустя десятилетия практикуют в роли шаманов. Очень часто это люди с психологическим образованием. Очевидно, им шаманская практика была нужна для сравнения с методами психологии и психотерапии. Кто-то просто добирал в свою профессиональную копилку экзотические техники, учитывая большой спрос, возникший на них у экзальтированного населения, а дальше это использовалось как вариант лечебно-оздоровительной практики конкретного психолога-шамана.

Интересно, что кое-кто из таких учеников приобщился к предлагаемому варианту шаманизма настолько глубоко и серьезно, что тувинская культура стала для него частью его повседневной жизни и практики.

Например, до сих пор в Москве практикует психолог Р. Ю. Нестеров, которого больше двух десятилетий назад выбрал в ученики Сайлык-оол Иванович-оол Канчыыр-оол на одном из своих семинаров, куда психолог заглянул ради сбора материала для своей квалификационной работы в университете. Роман Нестеров в итоге оказался не просто посвященным шаманом, но принятым в тувинский род и наследовавшим практику своего учителя после его ухода из жизни (с получением большей части ритуального одеяния и атрибутов).

Второй широко известный пример - Вера Сажина, также психолог по образованию, наследовавшая практику своего учителя и создавшая на его родине в Туве шаманскую организацию, где она много лет практиковала сама вместе с местными помощницами-шаманками.

Вот как описывает ее приобщение к тувинскому шаманизму взявшая у нее интервью Саяна Маеркова:

«...Вера решила ехать в Туву, где шаманизм официально признан одной из официальных религий.

Там ее взял в ученицы старый шаман, испросив перед тем разрешения у своих духов. Выучившись, она прошла посвящение в шаманы. О том, что происходит во время ритуала, не рассказывает никто. Это мучительная тайна, о которой Вера загадочно сказала:

- Во время посвящения внутренности буквально выворачиваются. Что-то исторгается изнутри. И все внутри меняется.

... Когда Вера не в Туве, она проводит в этой комнате (в московской квартире. $B . X$.$) почти все время.$

- Мой учитель был мужчина, поэтому я считаюсь не шаманкой, а шаманом. Во время камлания (вызывание духов) в меня вселяется мужской дух, - объясняет Вера. - После смерти учителя я получила в наследство его шаманский бубен. Бубен для меня как живое существо. В нем собрана вся боль шамана.

Тува стала второй родиной Веры. Она выучила тувинский язык, тамошний народ ее любит, она многим помогла» (Русская стала шаманкой, Электр. ресурс).

Столичные ученики шаманов, кстати, обычно помогали им в их продвижении на Запад, выполняя роль переводчиков и менеджеров, занимавшихся орга- 
низацией их поездок. В. Л. Сажина на протяжении многих лет дружбы с АйЧурек ездила вместе с ней в загранпоездки, помогая подруге, и сама принимала клиентов. Помощницы тувинских шаманов могли заниматься и контактами со средствами массовой информации.

\section{Жречество и целительство, искусство и наука...}

Обратим внимание на то, что сейчас Вера Сажина больше занимается своей концертной деятельностью, чем шаманизмом, но это для нее совершенно органично - это ее индивидуальный путь, ее судьба, ее жизнь:

«Коренные американцы и тувинские степи научили меня молиться, обращаясь к небу. Подмосковные сосновые леса научили меня настраиваться на волну волчьего радио. Крымское море обучило меня исполнять песни в состоянии глубокой медитации», - говорит Сажина (Кёко Нумано ..., 2016: Электр. ресурс).

О творческом начале в деятельности многих других шаманов и шаманок также известно. Ай Чурек, о которой можно много рассказывать, была не просто одной из интереснейших современных шаманок Тувы: она известна как прекрасная исполнительница алгышей, участница различных постановочных действ (например, во время Всемирной театральной олимпиады в Москве в 2001 г.), несколько раз участвовала в Международном фестивале «Устуу-Хурээ» (г. Чадан, Тува), принимала участие в Азиатском фестивале в Чикаго (США), джазовом фестивале в Швейцарии, фестивале этнической музыки «Саянское кольцо» (Республика Хакасия); в 2004 г. она записала авторский CD «Чугурук кежик» - сборник алгышей, открывающих «белую дорогу» и призывающих счастье и удачу.

Вместе с тем эта волевая женщина была отличным организатором и руководителем доверенного ей М. Б. Кенин-Лопсаном МРОШ «Тос-Дээр», в рамках которого существовал центр ее имени. Обратим внимание на то, что на некоторых сайтах до сих пор сохраняются объявления о его деятельности, где-то даже информация о ценах и услугах дается на текущий 2018 год: «Центр “Ай-Чурек” вместе с шаманской клиникой расположен в помещении шаманской организации “Тосс-Дээр”, которую тоже возглавляет Ай-Чурек Оюн. Здесь проводятся всевозможные семинары на тему привлечения счастья, богатства, здоровья и долголетия, а также прикладные занятия по горловому пению, предсказанию на камнях и т. д. В качестве индивидуальных обрядов практикуется шаманский массаж, очищение бубном, традиционный шаманский ритуал камлание и т. д.» (Шаманский центр ..., Электр. ресурс).

Шаманы МРОШ «Тос Дээр» и «Дунгур» под руководством Ай Чурек участвовали в различных общественных мероприятиях (во время Наадыма, например), организовывали и проводили календарные праздники (особенно важным среди них был Шагаа - встреча Нового года). Всё это требовало значительных актерских и режиссерских способностей. 
А вот создание священных мест оваа с проведением камланий на них, обеспечивающих благополучие всем, было вариантом жреческой практики. Такие ритуалы Ай Чурек могла приурочить к проведению научных мероприятий. Так, в 2001 г. во время Международного интердисциплинарного научно-практического симпозиума «Экология и традиционные религиозно-магические знания», который проводил Институт этнологии и антропологии Российской академии наук совместно с Хакасским научно-исследовательским институтом языка, литературы и истории (ХакНИИЯЛИ, г. Абакан) и Тувинским институтом гуманитарных исследований (ТИГИ, г. Кызыл) (Харитонова, Ревуненкова и др. 2002), в период пребывания международной группы ученых в Туве под руководством Ай Чурек с ее непосредственным участием было проведено несколько камланий, где она вместе с другими шаманами представала то в жреческой функции, то в целительской.

Особенно интересным оказался выезд на аржаан «Арголик» (Уургайлыг) в Тандинский кожуун Тувы летом 2001 года, где, как правило, находится много паломников, стремящихся улучшить здоровье. Изначально там планировалось проведение жреческого ритуала. Но приезд большого числа шаманов не остался незамеченным: паломники толпой пошли к священному месту, где обычно камлали шаманы, окружили их и стали просить о помощи. Шаманы, каждый из которых понимал, что не может отказывать страждущим, тут же начали работать с ними (массажи, очистительные ритуалы, советы по лечению, питанию, поведению и т. д.). Ситуация вышла из-под контроля, и Ай Чурек пришлось изменить план нашего пребывания на источниках: два часа было отведено на помощь больным, а после этого уже проводился общий очистительный ритуал и камлание у огня.

Стоит обратить внимание, что для современных шаманов важно не только сочетание в их деятельности жречества и целительства, не только обрядоворитуальная практика как таковая с ее возможностями выразить свой творческий потенциал и реализовать режиссерские способности. Для большинства из них важно быть участником научных мероприятий, быть причастным к исследованиям шаманских психофизиологических состояний и измененных состояний сознания, поскольку они, как люди современные и часто имеющие высокий уровень образования, стремятся сами к постижению феномена шаманизма с научных позиций.

Так, например, во время исследовательской интердисциплинарной экспедиции в 2004 г., работавшей под моим руководством в Кызыле, члены шаманских организаций без каких-либо сложностей с их стороны проходили нейрофизиологическое обследование и психологическое тестирование. Однако не случайно в печатных источниках (естественно, преимущественно в СМИ) упоминаются обычно не эти научные мероприятия, а то, что представляется для самих шаманов гораздо более интересным и значимым - их встречи с коллегамишаманами из других стран мира, первая из которых состоялась по инициативе финского исследователя Хеймо Лапполайнена и М. Б. Кенин-Лопсана в 1993 г., 
а вторая - десять лет спустя. Именно эти мероприятия они оценивают как научные симпозиумы.

Для кого-то из тувинских шаманов важнейшими и воспринимаемыми как научные становятся собрания народных целителей, в которых обычно участвует и довольно большое количество ученых - специалистов, исследующих феномены исцеления, способов лечения и оздоровления и т. д. В Туве есть новые шаманы, получившие в Москве сертификаты «народных целителей России». Например, такой документ получил известный хоомейжи, когда стал шаманомцелителем Николай Мунзукович Ооржак. Он на протяжении многих лет участвует в конгрессах и конференциях, организуемых Российской ассоциацией народной медицины (РАНМ), где, кстати, обычно проводит мастер-классы по своей методике оздоровления с помощью горлового пения.

\section{Лечит ли иаман?}

О Туве часто говорят как о некоем регионе, где шаманы работают едва ли не вместе с врачами: «Но в Тыве ${ }^{1}$ шаманизм процветает. В республике есть множество шаманских клиник. Если человек, например, чем-то заболел, то он может позвать не только врача, но и шамана. И более того - даже если больной уже находится в государственной больнице, он и туда может вызвать себе шамана» (Давыдов, 2009: Электр. ресурс).

На самом деле в 1990-е годы ситуация была близка к тому, как ее описал журналист. Однако со временем (особенно в свете корректирования законодательных статей о целительстве, введенных в Закон об охране здоровья граждан РФ в 1993 г.) и там изменилась общая картина трансформации шаманизма и развития его новых форм, равно как взаимоотношения шаманов и врачей (см.: Вяткина, 2018: Электр. ресурс; Харитонова, 2018: Электр. ресурс).

Сейчас я хочу обратить внимание на другой вопрос: можем ли мы говорить о том, что шаман именно «лечит»? Этот термин не рекомендуется использовать по отношению к подобным практикам (хотя в основных статьях Закона 1993 г. - в 56-й и 57-й, равно как в Общероссийском классификаторе занятий ГК РФ по стандартизации и метрологии (Постановление № 298 от 13.12.93) в характеристике составной группы 324 - Целители и практики нетрадиционной медицины» - речь шла именно о лечении).

Надо сказать, что сами знатоки традиции шаманское целительство не приравнивают к процессу лечения (хотя шаманы, как и узкие специалисты в медицине, могли заниматься, в том числе, конкретными лечебными делами). Глубоко проникшая в суть традиции психолог В. Л. Сажина так характеризовала в 2009 г. спектр деятельности шамана:

${ }^{1}$ Весьма распространившееся в последние годы склонение топонима на тувинском языке «Тыва» по правилам русского языка мы считаем неправильным. Правильно по-русски «в Туве». - peд. 


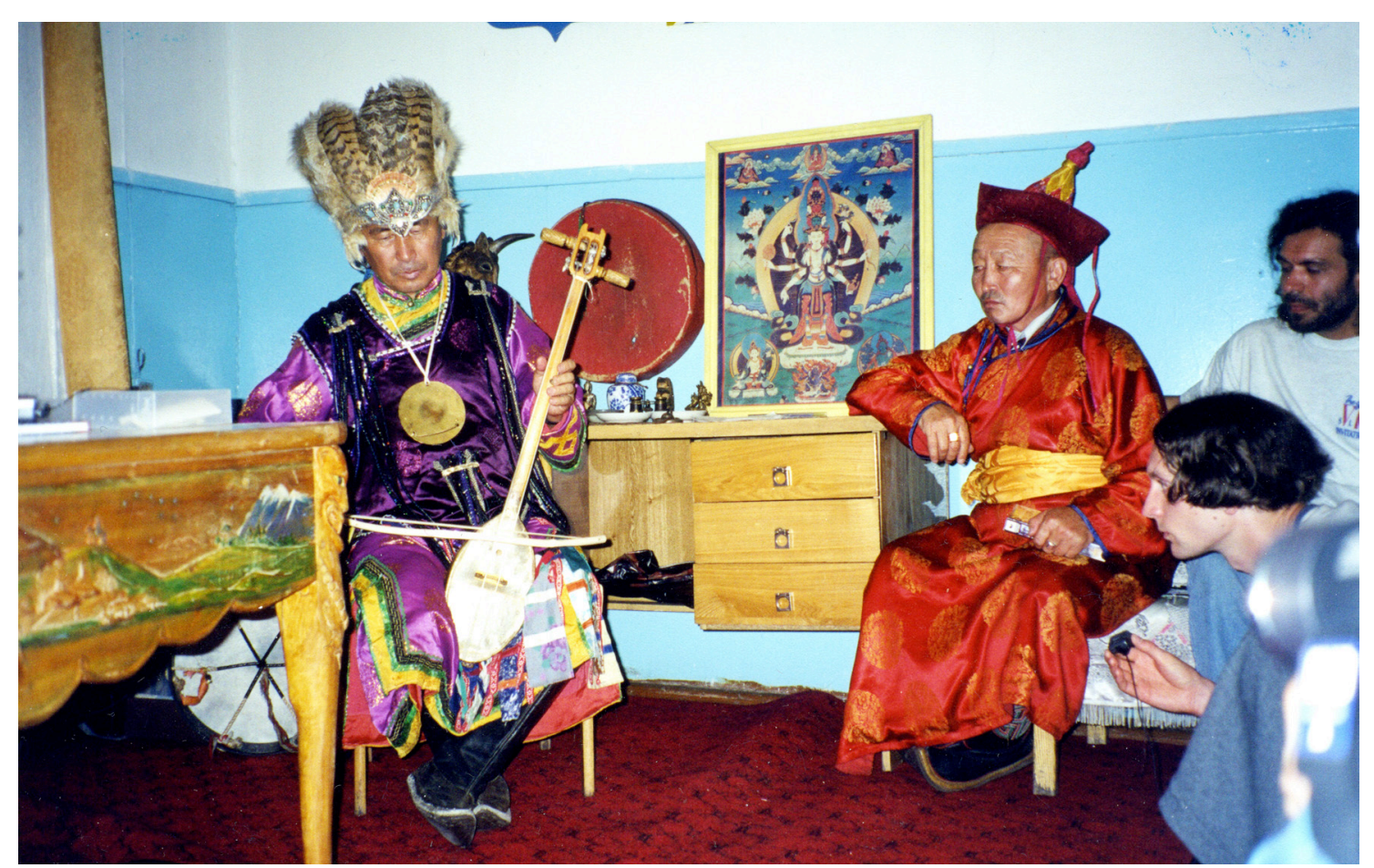

Фото 4. Ооржак Николай Мунзукович и Канчыыр-оол Сайлык-оол Иванович во время Международного интердисциплинарного научно-практического симпозиума «Экология и традиционные религиозно-магические знания» в Доме шаманизма «Хаттыг Тайга», фото В. И. Харитоновой, 20012.

Photo 4. Nikolai Munzukovich Oorzhak an Sailyk-Ool Ivanovich Kanchyyr-Ool at the international interdisciplinary research and practical symposium "Ecology and traditional religious and magical knowledge" at the Hattyg Taiga house of shamanism. Photo by V. I. Kharitonova, 2001.

«Обычно шамана приглашают люди, когда у них есть какая-то нужда, потребность ... Чтобы очистить дом, создать радостные отношения в семье, предотвратить несчастье, остановить смерть, если кто-то умер в доме из родственников. Вывести из дома духов умерших и опасных вредоносных духов. Чтобы рождались дети в доме и было благополучие. Иногда для совершения обряда на благополучие рода шамана вывозят в тайгу вместе со всей семьёй, там кормят духов тайги и совершают обряд, например, освящения шаманского дерева. Часто люди приходят в гости к шаману, в его дом. Например, чтобы им погадали. В процессе гадания шаман по вашей просьбе создаёт вам благополучную судьбу и создаёт преграды для злых сил, которые отнимают счастье, отнимают деньги и даже здоровье. Конечно, шаман ещё и лечит, снимает проклятия, порчу, сглаз... В общем, спектр деятельности шамана очень разнообразен» (Давыдов 2009: Эл. ресурс).

Лечебные и целительские методы использовались и используются, естественно, во всех шаманских центрах Тувы. Они предлагаются и на различных мероприятиях. Например, на сайте «Зов 13-ти шаманов» в разделе «Что будет происходить?» указано не только проведение ритуалов на удачу, развитие способностей, танцев и хоомей, но в 2018 г. там было обещано буквально следующее: «Церемонии исцеления от любых болезней. Шаманские практики долголетия, продления молодости и гибкости тела... Рождение идеальных здо- 
ровых детей.... Исцеление бесплодия...» (Зов 13 шаманов ..., Электр. ресурс).

Глагол «лечить» воспринимается сейчас как процесс прикладного воздействия, оказание конкретной помощи (не магической или магико-мистической) при определенном заболевании. Он связывается и законодательно в отношении народной медицины со специальностью «деревенский лекарь» или «лекарь-травник», например. Шаман соотносится со сферой духовного целительства и с представлением о врачевании как говорении, нашептывании (см. этимологию слова «врач» от «врать», «върати» - говорить, нашептывать: см. подробно: Харитонова, 1994). Но такие представления, как уже указывалось, стерты у наших современников, особенно тех, кто не живет в регионах распространения шаманизма.

К современному шаману могут обратиться, зная свой медицинский диагноз. Люди, не имеющие отношения к шаманским культурам, часто ждут именно конкретной помощи, избавления от проявившегося заболевания - снятия диагноза. Они могут удивиться, если им вместо лечения венозной недостаточности, например, или гипертонии предлагается установить контакты со своим родом, предками, о каких они подзабыли, или провести ритуал очищения - себя, дома, близких. Но шаман - не лекарь, он своеобразный духовный целитель, который заботится о восстановлении всех связей человека с родом, природой, космосом. И в этом смысле функции шамана не отменяют функции лекаря-прикладника травника, натуропата, костоправа - наоборот, они дополняют друг друга (если шаман не взял на себя еще и обязанности лекаря).

Шаман не лечит - он создает условия для исцеления, которое повлечет за собой излечение, процесс будет идти от глобальных, общих трансформаций к частным, вплоть до избавления от конкретных страданий. Эта философия шаманизма заложена в схему помощи шамана и лекаря человеку в шаманском сообществе.

Шаман, особенно в его современном варианте, стремится охватить разные сферы деятельности, соединяя жречество, целительство и даже осваивая прикладное ле́карство. Одно из важнейших его устремлений - развитие творческих способностей через погружение в необычные состояния - фактически, исследование техник ИСС - измененных состояний сознания (не случайно великие режиссеры обращались к изучению древних практик шаманизма в своих попытках совершенствования театрального искусства - этим известны К. С. Станиславский, Ежи Гратовский, Анатолий Васильев и др.). Обратим внимание, что организаторы фестиваля «Зов 13-ти шаманов» предлагали своим участникам погрузиться в развитие творческих способностей, ставя их рядом с необычными способностями, на сайте значится: «Раскрытие CBEPXспособностей. Ясновидение, целительство, общение с природой, яснознание. Раскрытие творческих способностей для будущей жизни» (Зов 13 шаманов ..., Электр. ресурс). 


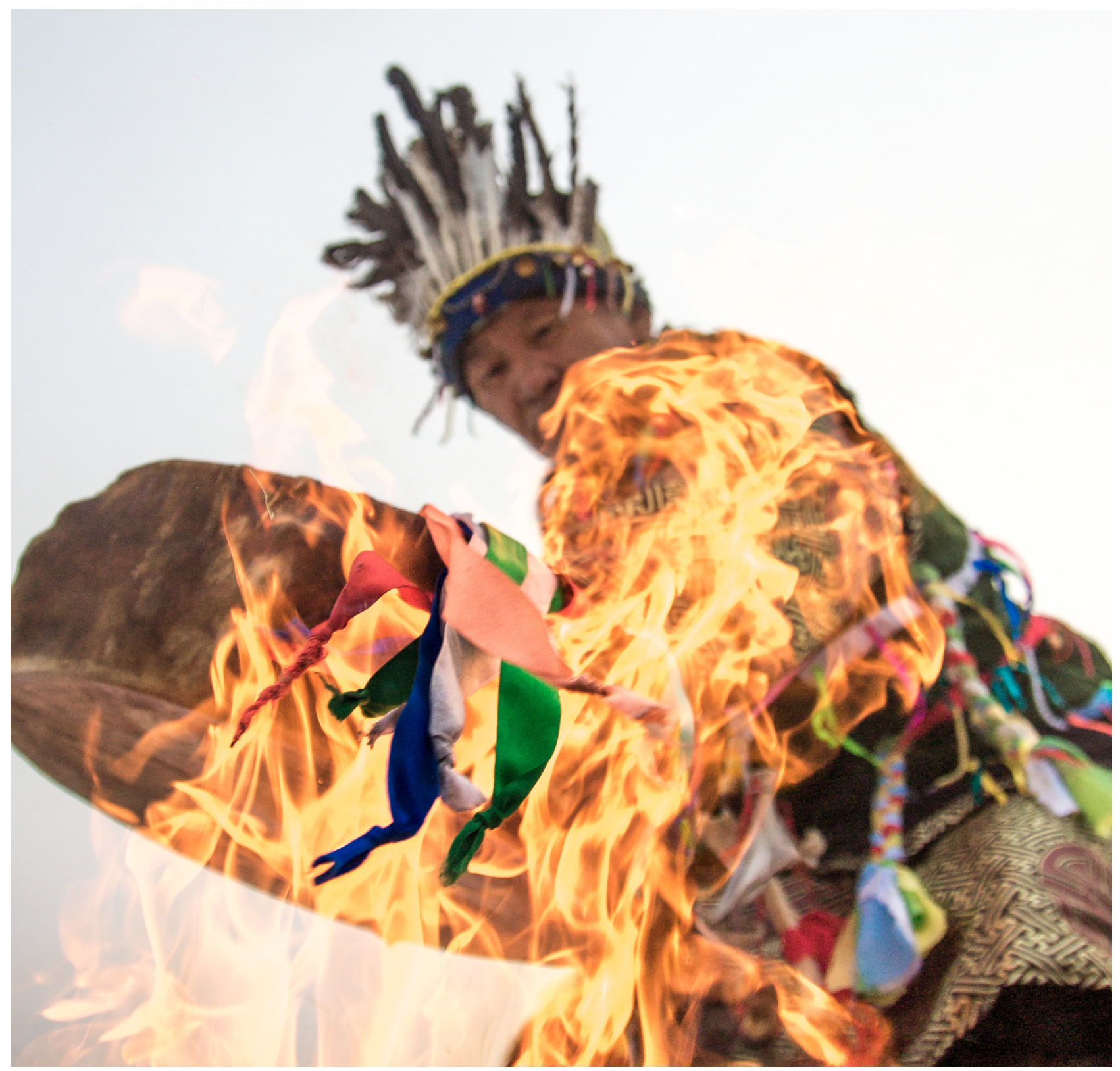

Фото 5. Шаман Вячеслав Монгеевич Оюн (Эргек-хам). Фото Владимира Монгуша, 2018 г. Photo 5. Vyacheslav Mongeevich Oyun (Ergek-kham), a shaman. Photo by Vladimir Mongush, 2018.

\section{Заключение}

Итак, что же происходит с современным (нео)шаманизмом (общий и детальный очерк которого трудно предложить, поскольку это было бы задачей объять необъятное)?

Можно сказать, что «шаманизм» в разных вариантах стал у нас массовым явлением: «шаманские практики» осуществляются в московских квартирах, 
залах для тренингов, выставок или театральных выступлений. Проводить тренинги едут на туристические «священные места» (о. Ольхон, например), к известным (нео)шаманам Сибири. Конечно, деятельность (нео)шаманов активно осуществляется на местах - в регионах, где ранее был развит шаманизм. И это вполне естественно в свете желания любого человека познать непознанное. Но тяга к «шаманскому» знанию фиксирует разных людей на различных вариантах того многомерного феномена, который обозначается этим термином. Поэтому кто-то концентрируется на религиозно-мистических и жреческих функциях, соотнося их с шаманизмом (например, «Александр Саввинов - глава религии Айыы» предлагает своим слушателям 2 октября 2018 г. в Москве семинар-практику; Шаманское путешествие + обряд»); ктото активно занимается лечением и исцелением, кто-то создает бубны... Но все интересующиеся «шаманизмом», - как правило, люди творческие, ездящие по разным странам мира (например, из Тувы во время фестиваля «Зов 13 шаманов» народ уже собирался в «Перуанскую Амазонию», которая теперь стала особенно популярна как место проведения церемоний с использованием известного галлюциногенного отвара трав - аяуаски). Они пишут стихи (прошу прощения, как правило, плохие), танцуют, поют... Реализуют себя через идею шаманизма.

Понятно, что чем больше приезжих «городских шаманов» в Туве, тем более разнообразны представления о том, что такое «шаманизм»: разносторонние познания сторонних лиц и распространение этих знаний среди местных (нео) шаманов приводят к тому, что ещё недавно нормально существовавшая традиция значимо трансформируется (ср.: Харитонова, 2001с, 2006b). Однако в Туве до настоящего времени есть те, кто пытается сохранять и культовые практики (в меру своих познаний о них), и лечебно-оздоровительную составляющую шаманизма.

Рассмотрение культурно-религиозной ситуации в Туве и отголосков ее в России и различных странах мира довольно четко демонстрирует нам, что культовые и целительские практики тувинцев - разумеется, в значительной степени трансформированные и модернизированные, не просто сохраняются и активно представлены сейчас в самой республике, но они распространяются по разным уголкам России и другим странам мира - мира, где цивилизация, давящая магико-мистические начала, приводит в итоге к неожиданному всплеску интереса к ним - порождает Нью Эйдж ${ }^{1}$, а заодно и возрождает интерес к традициям, знаниям предков, актуализируя их в неожиданных порой вариантах.

\footnotetext{
${ }^{1}$ Нью Эйдж (англ. New Age, букв, «новая эра») - общее название совокупности различных мистических течений и движений, в основном оккультного, эзотерического и синкретического характера. Сформировалось в 1970-е гг.
} 


\section{СПИСОК ЛИТЕРАТУРЫ}

Федеральный закон от 26.09.1997 N 125-Ф3 «О свободе совести и о религиозных объединениях» [Электронный ресурс] // КонсультантПлюс. URL: http://www.consultant.ru/document/cons_doc_LAW_16218/5d62cd14eedd618431cd9dbc8e4ed1ee64b0f7be/ (дата обращения: 15.09.2018).

Закон Республики Тыва от 01.04.1995 № 253 (ред. от 22.06.2005) «О свободе совести и религиозных организациях» (принят BX PT 16.03.1995) [Электронный ресурс] // Республика Тыва. URL: http://tuva.news-city.info/docs/sistemss/dok_ieydwo.htm (дата обращения: 15.09.2018).

В Германии издана книга Монгуша Кенин-Лопсана «Мифы тувинских шаманов» (2011) // Тува.Азия. 11 августа. URL: https://www.tuva.asia/news/tuva/3731-kenin-lopsan-germaniya (дата обращения: 10.09.2018).

Вайнштейн, С. И. (1990) Очерк тувинского шаманства // Традиционная обрядность и мировоззрение малых народов Севера / отв. ред И. С. Гурвич, 3. П. Соколова. М. : ИЭА РАН. 221 с. С. 160-195.

Вайнштейн, С. И. (1991) Мир кочевников Центра Азии. М. : Наука. 296 с.

Вяткина, Н. А. (2018) Народная медицина тувинцев глазами врачей (по материалам опроса врачей и другого медицинского персонала в Республике Тыва и соседних регионах) [Электронный ресурс] // Новые исследования Тувы. № 4. URL: https://nit. tuva.asia/nit/article/view/807 (дата обращения: 02.12.2018). DOI: 10.25178/nit.2018.4.4

Гроф, С. (1993) За пределами мозга : пер. с англ. 2-е изд. М. : Издательство Трансперсонального института. 504 с.

Гроф, С. (2018) Психология будущего. Уроки современных исследований сознания. М. : Ганга. 544 с.

Давыдов, Г. (2009) Шаманизм - в мегаполисы! [Электронный ресурс] // Частный корреспондент. 22 сентября. URL: http://www.chaskor.ru/article/shamanizm_-_v_megapolisy_10481 (дата обращения: 15.09.2018).

Дьяконова, В. П. (1972) К изучению шаманства у тувинцев (полевой сезон 1971 г.) // Краткое содержание докладов годичной научной сессии Института этнографии АН СССР / отв. ред. К. В. Чистов. Л. : Наука. 107 с. С. 27-28.

Женщина и возрождение шаманизма: постсоветское пространство на рубеже тысячелетий (2005) / Этнологические исследования по шаманству и иным традиционным верованиям и практикам. Т. 11 / отв. ред. В. И. Харитонова. М. : ИЭА РАН. 365 с.

Зов 13 шаманов. Международный этнический фестиваль. Тува 2018. 25-30 июня (2018) [Электронный ресурс] // Зов 13 шаманов. URL: http://13shamans.ru/ru/ (дата обращения: 15.09.2018).

«Избранники духов» - «избравшие духов»: традиционное шаманство и неошаманизм. Памяти В. Н. Басилова (1937-1998) (1999) : сборник статей / отв. ред. В. И. Харитонова. М. : ИЭА РАН. 308 с.

Ингерман, С. (2001) Возвращение души. Восстановление разбитого на части Я / пер. с англ. Н. Шпет. Киев : София. 256 с.

Кальвайт, Х. (1998) Шаманы, целители, знахари. Древнейшие учения, дарованные самой жизнью : пер. с нем. М. : Издат. дом «Совершенство». 224 с. 
Кёко Нумано (Kyoko Numano) (2016) Московская шаманка Вера Сажина [Электронный ресурс] // ИноСМИ. 5 августа. URL: https://inosmi.ru/social/20160805/237451383. html (дата обращения: 15.09.2018).

Кенин-Лопсан, М. Б. (1987) Обрядовая практика и фольклор тувинского шаманства. Конец XIX - начало XX в. Новосибирск : Наука. 165 с.

Кенин-Лопсан, М.Б. (2006) Традиционная культура тувинцев. Кызыл : Тувинское книжное издательство. 232 с.

Кенин-Лопсан, М. Б. (2009) Тувинские шаманы. М. : Маска. 325 с.

Монгуш Кенин-Лопсан: «Шаман живет в каждом из нас» (2007) [Электронный ресурс] // Профиль. 12 февраля. URL: https://profile.ru/arkhiv/item/52737-items_21949 (дата обращения: 10.09.2018).

Оюн, Д. (2004) Два месяца продлится американский тур тувинской шаманки АйЧурек (Лунное сердце) и группы «Чиргилчин» [Электронный ресурс]//ИА«Туваонлайн». 2 апреля. URL: https://www.tuvaonline.ru/2004/04/02/dva-mesyaca-prodlitsya-amerikanskiy-tur-tuvinskoy-shamanki-ay-churek-lunnoe-serdce-i-gruppy-quot-chirgilchin-quot. html (дата обращения: 10.09.2018).

Оюн, Д. (2012) Шаман общества «Дунгур» Дугар-Сюрюн Ооржак провел семинары в Австрии [Электронный ресурс] // ИА «Туваонлайн». 26 октября. URL: https://www. tuvaonline.ru/2012/10/26/shaman-obschestva-dungur-dugar-syuryun-oorzhak-provel-seminary-v-avstrii.html (дата обращения: 15.09.2018).

Пименова, К. В. (2007) Возрождение и трансформации традиционных верований и практик тувинцев в постсоветский период (основные проблемы) : дисс.... канд. ист. н. M. 310 c.

Русская стала шаманкой (2014) [Электронный ресурс] // LiveJournal. 22 мая. URL: https://sayanarus.livejournal.com/64276.html (дата обращения: 15.09.2018).

Скрыльников, П. (2018) ««Дух Медведя» выбрал Верховного шамана: Тувинским опытом самоорганизации могут воспользоваться русскиенеоязычники» [Электронный peсурс] // НГ-Религия. 20 июня. URL: http://www.ng.ru/ng_religii/2018-06-20/11_444_ tuva.html (дата обращения: 15.09.2018).

Слон, Э. (2002) В Америке ожидают приезда тувинской шаманки Ай-Чурек [Электронный ресурс] // ИА «Туваонлайн», 24 июля. URL: https://www.tuvaonline. ru/2002/07/24/v-amerike-ozhidayut-priezda-tuvinskoy-shamanki-ay-churek.html (дата обращения: 15.09.2018).

Тувинская шаманка Ай-Чурек (Лунное сердце) выступит в Москве (2003) [Электронный ресурс] // ИА Туваонлайн. URL: https://www.tuvaonline.ru/2003/12/02/tuvinskaya-shamanka-ay-churek-lunnoe-serdce-vystupit-v-moskve.html (дата обращения: 15.09.2018).

Харитонова, В. И. (1994) «Врач» от слова «врать» или степень родства колдовства и народного целительства // VITA. Традиции. Медицина. Здоровье. № 2. С. 2-5.

Харитонова, В. И. (1999) Заговорно-заклинательное искусство восточных славян: проблемы традиционных исследований и возможности новых интерпретаций / Этнологические исследования по шаманству и иным традиционным верованиям и практикам. Т. 3, ч. 1-2. М. : ИЭА РАН. 602 с. 
Харитонова, В. И. (2000) «Весна Средневековья» накануне III тысячелетия (Магико-мистическая практика и «народное целительство» в Московском регионе) // Московский регион: этноконфессиональная ситуация / под ред. Б. Р. Логашова. М. : ИЭА РАН. 284 с. С. 262-282.

Харитонова, В. И. (2001а) Некоторые проблемы воздействия шамана, колдуна, целителя на человека и окружающую среду // Экология и традиционные религиозномагические знания : Материалы международного интердисциплинарного научнопрактического симпозиума / Т. 7.2. Экология и традиционные религиозно-магические знания. Сер. Этнологические исследования по шаманству и иным традиционным верованиям и практикам. М. : ИЭА РАН. 307 с. С. 43-54.

Харитонова, В. И. (2001b) Религиозно-магические практики Южной Сибири: трансформации традиций в постсоветскую эпоху // Экология и традиционные религиозномагические знания : Материалы международного интердисциплинарного научнопрактического симпозиума / Т. 7.2. Экология и традиционные религиозно-магические знания. Сер. Этнологические исследования по шаманству и иным традиционным верованиям и практикам. М. : ИЭА РАН. 307 с. С. 169-189.

Харитонова, В. И. (2001с) Тувинский шаманизм, год 2000-ый: проблемы функционирования практики и глобализация знания // Полевые исследования Института этнологии и антропологии РАН. М. : ИЭА РАН. С. 76-105.

Харитонова, В. И. (2004) Устами шамана глаголет... дух? К вопросу о шаманской психофизиологии и возможностях экспериментального изучения личности шамана // Полевые исследования Института этнологии и антропологии РАН. 2002. М. : Наука. С. 24-43.

Харитонова, В. И. (2005) Зов предков или призыв духов? (Психо-физиологический и гендерный аспекты шаманизма) // Женщина и возрождение шаманизма: постсоветское пространство на рубеже тысячелетий. М. : ИЭА РАН. С. 25-43.

Харитонова, В. И. (2006а) Феникс из пепла? Сибирский шаманизм на рубеже тысячелетий. М. : Наука. 372 с.

Харитонова В. И. (2006b) Меж двух огней: размышления о судьбе «Шаманских религиозных организаций» // Полевые исследования Института этнологии и антропологии РАН - 2006. М. : Наука. С. 193-216.

Харитонова, В. И. (2008) Современная религиозная ситуация в Республике Тыва // Тюркские народы Восточной Сибири / отв. ред. Д. А. Функ, Н. А. Алексеев. М. : Наука. 422 с. С. $166-184$.

Харитонова, В. И. (2009) «Шаманизм» в современной России: к проблеме возрождения // Этнографическое обозрение. № 6. С. 148-164.

Харитонова, В. И. (2013а) Диалог культур на языке шаманизма // Вестник истории, литературы, искусства. Альманах Отделения ИФН РАН. Т. ІХ. С. 93-112.

Харитонова, В. И. (2013b) «Возрождённый шаманизм» в России: контексты функционирования // Эпическое наследие и духовные практики в прошлом и настоящем. Памяти В. Н. Басилова : сборник статей / Этнологические исследования по шаманству и иным традиционным верованиям и практикам. Т. 15, ч. 1 / отв. ред. В. И. Харитонова. М. : ИЭА РАН. С. 238-259. 
Харитонова, В. И. (2014) Там, где бродят живые туманы [Электронный ресурс]// ARC: Anthropolpgical Research Centre. 26 ноября. URL: https://antropya.com/articles/ main/127/ (дата обращения: 15.09.2018).

Харитонова, В. И. (2016а) «А у нас все шаманы - православные...»: современный (нео)шаманизм и проблема культурной идентичности // Сибирские исторические исследования. № 1. С. 105-133.

Харитонова, В. И. (2016b) Шаманские духи: основа сакрального и средство сакрализации // Сибирские исторические исследования. № 4. С. 236-261. DOI: $10.17223 / 2312461 X / 14 / 13$

Харитонова, В. И. (2016с) Сакральность и сакрализация: социокультурные контексты современности (введение к специальной теме номера) // Сибирские исторические исследования. № 4. С. 185-190. DOI: 10.17223/2312461X/14/10

Харитонова, В. И. (2018) Народная и традиционная медицина: возможности интеграции медицинских систем, практик и методов в условиях современной Тувы [Электронный ресурс] // Новые исследования Тувы. № 4. URL: https://nit.tuva.asia/nit/ article/view/804 (дата обращения: 02.12.2018). DOI: 10.25178/nit.2018.4.1

Харитонова, В. И., Кенин-Лопсан, М. Б. (2000) «Шаманский дар» в представлениях тувинцев (Из тувинских материалов летней экспедиции РАН 2000 г.) // Шаманский дар. К 80-летию доктора исторических наук Анны Васльевны Смоляк / Этнологические исследования по шаманству и иным традиционным верованиям и практикам. Т. 6./ отв. ред. В. И. Харитонова. М. : ИЭА РАН. 338 с. С. 55-78.

Харитонова, В. И., Ревуненкова, Е. В., Эдж, Х., Майклсон, С. (2002) Международный интердисциплинарный научно-практический симпозиум «Экология и традиционные религиозно-магические знания» // Этнографическое обозрение. № 6. С. 134-147.

Харитонова, В. И., Свидерская, Н. Е., Мещерякова Е. А. (2006) Шаманы и шаманизм в свете интердисциплинарных исследований // Полевые исследования института этнологии и антропологии РАН - 2004. М. : Наука. С. 128-149.

Харитонова, В. И., Топоев, В. С. (2005) Там, где «я» превращается в «мы» (психоментальные и психоэнергетические проблемы шаманизма сквозь призму комплексных исследований) // Итоги полевых исследований Института этнологии и антропологии РАН - 2004. М. : Наука. С. 83-103.

Шаманский центр «Ай-Чурек» [Электронный ресурс] // Тонкости туризма. URL: https://tonkosti.ru/Шаманский_центр_«Ай-Чурек» (дата обращения: 15.09.2018).

Штернберг, Л. Я. (1927) Избранничество в религии // Штернберг Л. Я. Этнография. Кн. III. Ч. І. Л. : АН СССР. С. 147-172.

Harner, M. J. (1980) The Way of the Shaman. N. Y. : Harper \& Row.

Jilek, W. G. (1982) Indian Healing - Shamanic Ceremonialism in the Pacific Northwest Today. Surrey, BC: Hancock House.

Kharitonova, V. (2005) Old woman tady's virtual drum. Traditional Sagai shamanism relics at the boundary of millennia // Acta Ethnographica Hungarica. 50 (1-3). P. 227-239.

Kharitonova, V., Ukraintseva, Yu. (2012) Destined for Shamanic Inspiration. An Integrative Study of Buryat (Neo)Shamans // Consciousness: Cultural and Therapeutic Perspectives / D. Eigner (ed.). Frankfurt a. M. : Peter Lang Publishing. 218 p. P. 109-130. 
Krippner, S. (2004) Psychology of Shamanism // Shamanism. An Encyclopedia of World Beliefs, Practices, and Culture / Ed. by M. N. Walter and E. J. Neumann Fridman. Santa Barbara, Calif. : ABC-CLIO. xxxi, 1055 p. Vol. I. Pp. 204-211.

Lindquist, G. (1997) Shamanic Performances on the Urban Scene: Neo-Shamanism in Contemporary Sweden. Stockh olm Studies in Social Anthropology, 39. Stockholm, Sweden: Almqvist \&Wiksell. 315 p.

Nauwald, N. (2015) Mein Word ist mächtig. Die Kraft der Worte in heilsamen Ritualen. AT Verkag. Aarau und München. $176 \mathrm{~s}$.

Pimenova, K. (2013) The 'Vertical of Shamanic Power'. The Use of Political Discourse in Post-Soviet Tuvan Shamanism» [Электронный ресурс] // Laboratorium : Russian Review of Social Research, vol. 5, no. 1. URL: http://soclabo.org/index.php/laboratorium/article/ view/63 (дата обращения: 15.09.2018).

Saudin, A., Allione, C. (1999) Ai-Tchourek... come la luna. Trance, guarigioni e riti sacri di una sciamana tuvina. Torino : Libreria Editrice Psiche. 78 p.

Shamanism in Siberia (1978). Ed. by V. Dioszegy and M. Hoppal. Budapest : Akademiai Kiado. 532 p.

Shamanism. An Encyclopedia of World Beliefs, Practices, and Culture (2004) / Ed. by M. N. Walter and E. J. Neumann Fridman. Santa Barbara, Calif. : ABC-CLIO. xxxi, 1055 p.

Townsend, J. B. (2004) Core Shamanism and Neo-Shamanism // Shamanism. An Encyclopedia of World Beliefs, Practices, and Culture / Ed. by M. N. Walter and E. J. Neumann Fridman. Santa Barbara, Calif. : ABC-CLIO. xxxi, 1055 p. Vol. I. P. 49-57.

Winkelnam, M. (2004) Neuropsychology of Shamanism // Shamanism. An Encyclopedia of World Beliefs, Practices, and Culture / Ed. by M. N. Walter and E. J. Neumann Fridman. Santa Barbara, Calif. : ABC-CLIO. xxxi, 1055 p. Vol. I. P. 187-195.

Дата поступления: 12.10 .2018 г.

\section{REFERENCES}

Federal'nyi zakon ot 26.09.1997 N 125-FZ «O svobode sovesti i o religioznykh ob"edineniiakh» [Federal law of 26.09.1997 N 125-FZ "On freedom of conscience and religious associations»]. Konsul'tantPlius [online] Available at: http://www.consultant.ru/document/cons_doc_LAW_16218/5d62cd14eedd618431cd9dbc8e4ed1ee64b0f7be/ (access date: 15.09.2018). (In Russ.).

Zakon Respubliki Tyva ot 01.04.1995 № 253 (red. ot 22.06.2005) «O svobode sovesti i religioznykh organizatsiiakh» (priniat VKh RT 16.03.1995) [Law of the Republic of Tuva of 01.04.1995 № 253 (as amended on 22.06.2005) "On freedom of conscience and religious organizations" (adopted by the Parliament of the Republic of Tuva 16.03.1995)]. Respublika Tyva [online] Available at: http://tuva.news-city.info/docs/sistemss/dok_ieydwo.htm (access date: 15.09.2018). (In Russ.).

V Germanii izdana kniga Mongusha Kenin-Lopsana «Mify tuvinskikh shamanov» [Mongush Kenin-Lopsan’s book “Myths of Tuvan shamans” published in Germany] (2011). Tuva. Asia, August 11 [online] Available at:https://www.tuva.asia/news/tuva/3731-kenin-lopsangermaniya (access date: 10.09.2018). (In Russ.). 
Vainshtein, S. I. (1990) Ocherk tuvinskogo shamanstva [An essay of Tuvan shamanism]. In: Traditsionnaia obriadnost' i mirovozzrenie malykh narodov Severa [Traditional ritual and worldview of the small peoples of the North] / ed by I. S. Gurvich and Z. S. Sokolova. Moscow, IEA RAN. 221 p. Pp. 160-195. (In Russ.).

Vainshtein, S. I. (1991) Mir kochevnikov tsentra Azii [The world of nomads of the center of Asia]. Moscow, Nauka. 296 p. (In Russ.).

Viatkina, N. A. (2018) Narodnaia meditsina tuvintsev glazami vrachei (po materialam oprosa vrachei i drugogo meditsinskogo personala v Respublike Tyva i sosednikh regionakh) [Tuvan folk medicine through doctors' eyes: a survey of physicians and other medical personnel in the Republic of Tuva and its environs]. The New Research of Tuva, no. 4 [online] Available at: https://nit.tuva.asia/nit/article/view/807 (access date: 02.12.2018). DOI: 10.25178/nit.2018.4.4 (In Russ.).

Grof, S. (1993) Za predelami mozga [Beyond the Brain] : transl. from Engl., 2nd ed. Moscow, Izdatel'stvo Transpersonal'nogo instituta. 504 p. (In Russ.).

Grof, S. (2018) Psikhologiia budushchego. Uroki sovremennykh issledovanii soznaniia [Psychology of the Future: Lessons from Modern Consciousness Research], transl. from Engl. Moscow, Ganga. 544 p. (In Russ.).

Davydov, G. (2009) Shamanizm - v megapolisy! [Bring shamanism to the big city]. Chastnyi correspondent, September 22 [online] Available at:http://www.chaskor.ru/article/ shamanizm___v_megapolisy_10481 (access date: 15.09.2018). (In Russ.).

D'iakonova, V. S. (1972) K izucheniiu shamanstva u tuvintsev (polevoi sezon 1971 g.) [On the study of shamanism in Tuva (field season of 1971)]. In: Kratkoe soderzhanie dokladov godichnoi nauchnoi sessii Instituta etnografii AN SSSR [Summary of reports of the annual scientific session of the Institute of Ethnography of the USSR] / ed. by K. V. Chistov. Leningrad, Nauka Publ. 107 p. Pp. 27-28. (In Russ.).

Zhenshchina i vozrozhdenie shamanizma: postsovetskoe prostranstvo na rubezhe tysiacheletii [Woman and the revival of shamanism: the post-Soviet space at the turn of the Millennium] (2005) / ed. by V. I. Kharitonova. Moscow, IEA RAN. 365 p. (In Russ.).

Zov 13 shamanov. Mezhdunarodnyi etnicheskii festival'. Tuva 2018. 25-30 iiunia [The call of the 13 shamans. An international ethnic festival. Tuva, 25-30 June 2018] (2018). Zov 13 shamanov [online] Available at:http://13shamanPp.ru/ru/ (access date: 15.09.2018). (In Russ.).

«Izbranniki dukhov» - «izbravshie dukhov»: traditsionnoe shamanstvo i neoshamanizm. Pamiati V. N. Basilova (1937-1998) ["Chosen by the spirits" - "choosers of the spirits": traditional shamanism and neoshamanism. To the memory of V. N. Basilov (1937-1998)] (1999) : a collection of articles / ed. by V. I. Kharitonova. Moscow, IEA RAN. 308 p. (In Russ.).

Ingerman, S. (2001) Vozvrashchenie dushi. Vosstanovlenie razbitogo na chasti Ia [Soul Retrieval: Mending the Fragmented Self] / transl. from Engl. By N. Shpet. Kiev, Sofiia. 256 p. (In Russ.).

Kal'vait, H. (1998) Shamany, tseliteli, znakhari. Drevneishie ucheniia, darovannye samoi zhizn'iu [Shamans, healers, medicine men. The ancient doctrine, given by life itself] : transl. from Germ. Moscow, Publishing house «Sovershenstvo». 224 p. (In Russ.).

Keko Numano (Kyoko Numano) (2016) Moskovskaia shamanka Vera Sazhina [Vera Sazhina, a Moscow shaman]. InoSMI, August 5 [online] Available at: https://inosmi.ru/social/20160805/237451383.html (access date: 15.09.2018). (In Russ.). 
Kenin-Lopsan, M. B. (1987) Obriadovaia praktika i fol'klor tuvinskogo shamanstva. Konets $X I X-$ nachalo XX v. [Ritual practice and folklore of Tuvinian shamanism. Late XIX - early XX century.]. Novosibirsk, Nauka. 165 p. (In Russ.).

Kenin-Lopsan, M. B. (2006) Traditsionnaia kul'tura tuvintsev [Traditional culture of Tuvans]. Kyzyl, Tuvan book publisher. 232 p. (In Russ.).

Kenin-Lopsan, M.B. (2009) Tuvinskie shamany [Tuvan shamans]. Moscow, Maska. 325 p. (In Russ.).

Mongush Kenin-Lopsan: «Shaman zhivet v kazhdom iz nas» (2007) [Mongush KeninLopsan: "The Shaman lives in each of us"]. Profil', February12 [online] Available at: https:// profile.ru/arkhiv/item/52737-items_21949 (access date: 10.09.2018). (In Russ.).

Oyun, D. (2004) Dva mesiatsa prodlitsia amerikanskii tur tuvinskoi shamanki Ai-Churek (Lunnoe serdtse) i gruppy «Chirgilchin» [The American tour of Tuvan shaman AI-Churek (Lunar Heart) and the group "Chirgilchin" to last two months]. IA «Tuvaonlin», April 2 [online] Available at:https://www.tuvaonline.ru/2004/04/02/dva-mesyaca-prodlitsya-amerikanskiy-tur-tuvinskoy-shamanki-ay-churek-lunnoe-serdce-i-gruppy-quot-chirgilchinquot.html (access date: 10.09.2018). (In Russ.).

Oyun, D. (2012) Shaman obshchestva «Dungur» Dugar-Siuriun Oorzhak provel seminary v Avstrii [Dugar-Surun Oorzhak, shaman of "Dungur" society, held seminars in Austria]. IA «Tuvaonline», October 26 [online] Available at:https://www.tuvaonline.ru/2012/10/26/ shaman-obschestva-dungur-dugar-syuryun-oorzhak-provel-seminary-v-avstrii.html (access date: 15.09.2018). (In Russ.).

Pimenova, K. V. (2007) Vozrozhdenie i transformatsii traditsionnykh verovanii i praktik tuvintsev $v$ postsovetskii period (osnovnye problemy) [Revival and transformation of traditional beliefs and practices of Tuvans in the post-Soviet period: main issues] : Diss.... Candidate of History. Moscow. 310 p. (In Russ.).

Russkaia stala shamankoi [A Russian woman became a shaman] (2014). LiveJournal, May 22 [online] Available at: https://sayanaruPp.livejournal.com/64276.html (access date: 15.09.2018). (In Russ.).

Skryl'nikov, S. (2018) «"Dukh Medvedia" vybral Verkhovnogo shamana: Tuvinskim opytom samoorganizatsii mogut vospol'zovat'sia russkie neoiazychniki» [«The Supreme shaman chosen by "the Spirit of the Bear": Russian neo-pagans can borrow from Tuvan experience of self-organization»]. NG-Religiia, June 20 [online] Available at: http://www.ng.ru/ ng_religii/2018-06-20/11_444_tuva.html (access date: 15.09.2018). (In Russ.).

Slon, E. (2002) V Amerike ozhidaiut priezda tuvinskoi shamanki Ai-Churek [America waiting for the arrival of the Tuvan shaman AI-Churek]. IA «Tuvaonline», Jule 24 [online] Available at:https://www.tuvaonline.ru/2002/07/24/v-amerike-ozhidayut-priezda-tuvinskoy-shamanki-ay-churek.html (access date: 15.09.2018). (In Russ.).

Tuvinskaia shamanka Ai-Churek (Lunnoe serdtse) vystupit v Moskve [Tuvan shaman AIChurek (Moon Heart) to perform in Moscow] (2003). IA “Tuvaonline”, December 2 [online] Available at:https://www.tuvaonline.ru/2003/12/02/tuvinskaya-shamanka-ay-churek-lunnoe-serdce-vystupit-v-moskve.html (access date: 15.09.2018). (In Russ.).

Kharitonova, V. I. (1994) «Vrach» ot slova «vrat'» ili stepen' rodstva koldovstva i narodnogo tselitel'stva ["Vrach" (Doctor)" is derived from "vrat" (to lie), or the degree of kin- 
ship between witchcraft and traditional healing]. VITA. Traditsii. Meditsina. Zdorov'e, no. 2, pp. 2-5. (In Russ.).

Kharitonova, V. I. (1999) Zagovorno-zaklinatel'noe iskusstvo vostochnykh slavian: problemy traditsionnykh issledovanii i vozmozhnosti novykh interpretatsii [The art of charming and conjuring among the Eastern Slavs: the problems of traditional research and the possibility of new interpretations]. Moscow, IEA RAN. 602 p. (In Russ.).

Kharitonova, V. I. (2000) «Vesna Srednevekov'ia» nakanune III tysiacheletiia (Magikomisticheskaia praktika $\mathrm{i}$ «narodnoe tselitel'stvo» $\mathrm{v}$ Moskovskom regione) ["Spring of the middle Ages" on the eve of the III Millennium (Magico-mystical practice and "folk healing" in the Moscow region)]. In: Moskovskii region: etnokonfessional'naia situatsiia [Moscow region: an ethno-confessional situation] / ed. by B. R. Logashova. Moscow, IEA RAN. 284 p. Pp. 262-282. (In Russ.).

Kharitonova, V. I. (2001a) Nekotorye problemy vozdeistviia shamana, kolduna, tselitelia na cheloveka i okruzhaiushchuiu sredu [Some problems of influence of the shaman, sorcerer, or healer on the person and environment]. In: Ekologiia i traditsionnye religioznomagicheskie znaniia [Ecology and traditional religious and magical knowledge] : Proceedings of the International interdisciplinary research and practical symposium. Moscow, IEA RAN. 307 p. Pp. 43-54. (In Russ.).

Kharitonova, V. I. (2001b) Religiozno-magicheskie praktiki Iuzhnoi Sibiri: transformatsii traditsii v postsovetskuiu epokhu [Religious and magical practices of southern Siberia: the transformation of traditions in the post-Soviet era]. In: Ekologiia i traditsionnye religioznomagicheskie znaniia [Ecology and traditional religious and magical knowledge] : Proceedings of the International interdisciplinary research and practical symposium. Moscow, IEA RAN. 307 p. Pp. $169-189$.

Kharitonova, V. I. (2001s) Tuvinskii shamanizm, god 2000-yi: problemy funktsionirovaniia praktiki i globalizatsiia znaniia [Tuvan shamanism, year 2000: problems of the practice and globalization of knowledge]. In: Polevye issledovaniia instituta etnologii $i$ antropologii $R A N$ [Field research of the Institute of Ethnology and anthropology RAS]. Moscow, IEA RAN. Pp. 76-105. (In Russ.).

Kharitonova, V. I. (2004) Ustami shamana glagolet... dukh? K voprosu o shamanskoi psikhofiziologii i vozmozhnostiakh eksperimental'nogo izucheniia lichnosti shamana) [Out of the mouth of the shaman come the words of ... the spirit? On the issue of shamanic psychophysiology and the possibilities of experimental study of the shaman's personality)]. In: Polevye issledovaniia Instituta etnologii i antropologii RAN. 2002 [Field research of the Institute of Ethnology and anthropology RAS. 2002]. Moscow, Nauka. Pp. 24-43. (In Russ.).

Kharitonova, V. I. (2005) Zov predkov ili prizyv dukhov? (Psikhofiziologicheskii i gendernyi aspekty shamanizma) [Call of the wild or call of the spirits? (Psychophysiological and gender aspects of shamanism)]. In: Zhenshchina $i$ vozrozhdenie shamanizma: postsovetskoe prostranstvo na rubezhe tysiacheletii [Woman and the revival of shamanism: the post-Soviet space at the turn of the Millennium] (2005) / ed. by V. I. Kharitonova. Moscow, IEA RAN. 365 p. Pp. 25-43. (In Russ.).

Kharitonova, V. I. (2006a) Feniks iz pepla? Sibirskii shamanizm na rubezhe tysiacheletii [A Phoenix from the ashes? Siberian shamanism at the turn of the Millennium.]. Moscow, Nauka. 372 p. (In Russ.). 
Kharitonova V. I. (2006b) Mezh dvukh ognei: razmyshleniia o sud'be «Shamanskikh religioznykh organizatsii» [Between two fires: reflections on the fate of "Shamanic religious organizations"]. In: Polevye issledovaniia Instituta etnologii i antropologii RAN - 2006 [Field research of Institute of Ethnology and anthropology RAS. 2006]. Moscow, Nauka. Pp. 193-216. (In Russ.).

Kharitonova, V. I. (2008) Sovremennaia religioznaia situatsiia v Respublike Tyva [The current religious situation in the Republic of Tuva]. In: Tiurkskie narody Vostochnoi Sibiri [The Turkic peoples of Eastern Siberia] / ed. by D. A. Funk and N. A. Alekseev. Moscow, Nauka. 422 p. Pp. 166-184. (In Russ.).

Kharitonova, V. I. (2009) «Shamanizm» v sovremennoi Rossii: k probleme vozrozhdeniia ["Shamanism" in modern Russia: to the problem of revival]. Etnograficheskoe obozrenie, no. 6, pp. 148-164. (In Russ.).

Kharitonova, V. I. (2013a) Dialog kul'tur na iazyke shamanizma [Dialogue of cultures in the language of shamanism]. Vestnik istorii, literatury, iskusstva. Al'manakh Otdeleniia IFN $R A N$, vol. IX, pp. 93-112. (In Russ.).

Kharitonova, V. I. (2013b) «Vozrozhdennyi shamanizm»v Rossii: konteksty funktsionirovaniia ["Revived shamanism" in Russia: contexts of functioning]. In: Epicheskoe nasledie $i$ dukhovnye praktiki $v$ proshlom i nastoiashchem. Pamiati V. N. Basilova [Epic heritage and spiritual practices in the past and present. In the memory of V. N. Basilov] : a collection of articles / ed. by V. I. Kharitonova. Moscow, IEA RAN. Pp. 238-259. (In Russ.).

Kharitonova, V. I. (2014) Tam, gde brodiat zhivye tumany [Where the living mists roam]. ARC: Anthropolpgical Research Centre, November 26 [online] Available at: https://antropya. com/articles/main/127/ (access date: 15.09.2018). (In Russ.).

Kharitonova, V. I. (2016a) «A u nas vse shamany - pravoslavnye...»: sovremennyi (neo) shamanizm i problema kul'turnoi identichnosti ["Our shamans are all Orthodox Christians...": modern (neo)shamanism and the issue of cultural identity]. Siberian Historical Research, no. 1, pp. 105-133. DOI: 10.17223/2312461X/11/8 (In Russ.).

Kharitonova, V. I. (2016b) Shamanskie dukhi: osnova sakral'nogo i sredstvo sakralizatsii [Shamanic spirits: the basis of the sacral and the means of sacralization]. Siberian Historical Research, no. 4, pp. 236-261. DOI: 10.17223/2312461X/14/13 (In Russ.).

Kharitonova, V. I. (2016c) Sakral'nost' i sakralizatsiia: sotsiokul'turnye konteksty sovremennosti (vvedenie k spetsial'noi teme nomera) [Sacredness and sacralization: sociocultural contexts of contemporaneity: An introduction to the special theme of the issue)]. Siberian Historical Research, no. 4, pp. 185-190. DOI: 10.17223/2312461X/14/10 (In Russ.).

Kharitonova, V. I. (2018) Narodnaia i traditsionnaia meditsina: vozmozhnosti integratsii meditsinskikh sistem, praktik i metodov v usloviiakh sovremennoi Tuvy [Folk and traditional medicine: On the possibility of integrating medical systems, practices and methods in contemporary Tuva]. The New Research of Tuva, no. 4 [online] Available at: https://nit.tuva.asia/ nit/article/view/804 (access date: 02.12.2018). DOI: 10.25178/nit.2018.4.1 (In Russ.).

Kharitonova, V. I. and Kenin-Lopsan, M. B. (2000) «Shamanskii dar» V predstavleniiakh tuvintsev (Iz tuvinskikh materialov letnei ekspeditsii RAN 2000 g.) ["Shamanic gift" in the views of Tuvans (Tuvan materials of the 2000 summer expedition of RAS). In: Shamanskii dar. K 80-letiiu doktora istoricheskikh nauk Anny Vasl'evny Smoliak [Shamanic gift. A Festschrift for the 80th anniversary of doctor of historical Sciences Anna Smolyak], ed. V. I. Kharitonova. Moscow, IEA RAN. 338 p. Pp. 55-78. (In Russ.). 
Kharitonova, V. I. and Revunenkova, E. V., Edzh, Kh. and Maiklson, S. (2002) Mezhdunarodnyi interdistsiplinarnyi nauchno-prakticheskii simpozium «Ekologiia i traditsionnye religiozno-magicheskie znaniia» [International interdisciplinary research and practical symposium "Ecology and traditional religious and magical knowledge"]. Etnograficheskoe obozrenie, no. 6, pp. 134-147. (In Russ.).

Kharitonova, V. I., Sviderskaia, N. E. and Meshcheriakova E. A. (2006) Shamany i shamanizm v svete interdistsiplinarnykh issledovanii [Shamans and shamanism in the light of interdisciplinary research]. In: Polevye issledovaniia instituta etnologii i antropologii RAN2004 [Field research of the Institute of Ethnology and anthropology RAS. 2004]. Moscow, Nauka. Pp. 128-149. (In Russ.).

Kharitonova, V. I. and Topoev, V. PP. (2005) Tam, gde «ia» prevrashchaetsia V «my» (psikhomental'nye i psikhoenergeticheskie problemy shamanizma skvoz' prizmu kompleksnykh issledovanii) [Where the "I" turns into "We": Psychomental and psychoenergetic problems of shamanism through the prism of comprehensive research)]. In: Itogi polevykh issledovanii Instituta etnologii $i$ antropologii RAN - 2004 [Results of field studies of the Institute of Ethnology and anthropology RAS-2004]. Moscow, Nauka. Pp. 83-103. (In Russ.).

Shamanskii tsentr «Ai-Churek» [“Ai-Churek" shaman center]. Tonkosti turizma [online] Available at: https://tonkosti.ru/Shamanskii_tsentr_«Ai-Churek» (access date: 15.09.2018). (In Russ.).

Shternberg, L. Ia. (1927) Izbrannichestvo v religii [Electionism in religion]. In: Shternberg L. Ia. Etnografiia [Etnology]. Book III, vol. I. Leningrad, AN SSSR. Pp. 147-172. (In Russ.).

Harner, M. J. (1980) The Way of the Shaman. New York, Harper \& Row.

Jilek, W. G. (1982) Indian Healing - Shamanic Ceremonialism in the Pacific Northwest Today. Surrey, BC., Hancock House.

Kharitonova, V. (2005) Old woman tady's virtual drum. Traditional Sagai shamanism relics at the boundary of millennia. Acta Ethnographica Hungarica, no. 50 (1-3), pp. 227-239.

Kharitonova, V. and Ukraintseva, Yu. (2012) Destined for Shamanic Inspiration. An Integrative Study of Buryat (Neo)Shamans. In: Consciousness: Cultural and Therapeutic Perspectives / D. Eigner (ed.). Frankfurt a. M., Peter Lang Publishing. 218 p. Pp. 109-130.

Krippner, S. (2004) Psychology of Shamanism. In: Shamanism. An Encyclopedia of World Beliefs, Practices, and Culture / ed. by M. N. Walter and E. J. Neumann Fridman. Santa Barbara, Calif. : ABC-CLIO. xxxi, 1055 p. Vol. I. Pp. 204-211.

Lindquist, G. (1997) Shamanic Performances on the Urban Scene: Neo-Shamanism in Contemporary Sweden. Stockh olm Studies in Social Anthropology, 39. Stockholm, Sweden, Almqvist \&Wiksell. 315 p.

Nauwald, N. (2015) Mein Word ist mächtig. Die Kraft der Worte in heilsamen Ritualen. AT Verkag. Aarau und München. $176 \mathrm{~s}$.

Pimenova, K. (2013) The 'Vertical of Shamanic Power'. The Use of Political Discourse in Post-Soviet Tuvan Shamanism».Laboratorium : Russian Review of Social Research, vol. 5, no. 1 URL: http://soclabo.org/index.php/laboratorium/article/view/63 (access date: 15.09.2018).

Saudin, A. and Allione, C. (1999) Ai-Tchourek... come la luna. Trance, guarigioni e riti sacri di una sciamana tuvina. Torino, Libreria Editrice Psiche. 78 p.

Shamanism in Siberia (1978). Ed. by V. Dioszegy and M. Hoppal. Budapest, Akademiai Kiado. 532 p. 
Shamanism. An Encyclopedia of World Beliefs, Practices, and Culture (2004) / Ed. by M. N. Walter and E. J. Neumann Fridman. Santa Barbara, Calif., ABC-CLIO. xxxi, 1055 p.

Townsend, J. B. (2004) Core Shamanism and Neo-Shamanism. In: Shamanism. An Encyclopedia of World Beliefs, Practices, and Culture / Ed. by M. N. Walter and E. J. Neumann Fridman. Santa Barbara, Calif., ABC-CLIO. xxxi, 1055 p. Vol. I. Pp. 49-57.

Winkelnam, M. (2004) Neuropsychology of Shamanism. In: Shamanism. An Encyclopedia of World Beliefs, Practices, and Culture / Ed. by M. N. Walter and E. J. Neumann Fridman. Santa Barbara, Calif., ABC-CLIO. xxxi, 1055 p. Vol. I. Pp. 187-195.

Submission date: 12.10 .2018$.

\section{Для цитирования:}

Харитонова В. И. Тувинский (нео)шаманизм как культовая и целительская практика в современном мире [Электронный ресурс]// Новые исследования Тувы. 2018, № 4. URL: https://nit.tuva.asia/nit/article/view/806 (дата обращения: дд.мм.гг.). DOI: $10.25178 /$ nit.2018.4.3

\section{For citation:}

Kharitonova V. I. Tuvan (neo) shamanism as a religious and healing practice in contemporary world. The New Research of Tuva, 2018, no. 4 [on-line] Available at: https:// nit.tuva.asia/nit/article/view/806 (accessed: ...). DOI: 10.25178/nit.2018.4.3 